\title{
Clear Cell Renal Carcinoma: MicroRNAs With Efficacy in Preclinical In Vivo Models
}

\author{
ULRICH H. WEIDLE and ADAM NOPORA
}

Roche Pharma Research and Early Development, Roche Innovation Center Munich, Penzberg, Germany

\begin{abstract}
In order to identify new targets and treatment modalities for clear cell renal carcinoma, we surveyed the literature with respect to microRNAs involved in this disease. In this review, we have focused on up- and down-regulated miRs which mediate efficacy in preclinical clear-cell renal carcinoma-related in vivo models. We have identified 10 upregulated and 33 down-regulated micro-RNAs according to this criterion. As proof-of-concept, micro-RNAs interfering with VEGF (miR-205p) and mTOR (mir-99a) pathways, which are modulated by approved drugs for this disease, have been identified. miRs targeting hypoxia induced factor$2 \alpha(H I F-2 \alpha)$ (miR-145), E3 ubiquitinylases speckle-type POZ protein (SPOP) (miR 520/372/373) and casitas B-lineage lymphoma (CBL) (miR-200a-3p), interfere with druggable targets. Further identified miRs interfere with cell-cycle dependent kinases, such as CDK2 (miR-200c), CDK4, 6 (miR-1) and CDK4, 9 (206c). Transmembrane receptor Ral interacting protein of $76 \mathrm{kD}(R L I P 76)$, targeted by mir-137, has emerged as another important target for $c c R C C$. Additional miRs and their targets merrying further preclinical validation are discussed.
\end{abstract}

In the US in 2020, 74,000 new cases of patients with renal cancer have been diagnosed and 15,000 patients have died (1). Renal cell carcinoma (RCC) develops in the lining of the

This article is freely accessible online.

Correspondence to: Adam Nopora, Roche Diagnostics GmbH, Nonnenwald 2, D-82372 Penzberg, Germany. Tel: +49 8856602552, e-mail: adam.nopora@roche.com; Ulrich H. Weidle, Roche Innovation Center Munich, Roche Diagnostics GmbH, Nonnenwald 2, D-82372 Penzberg, Germany. E-mail: weidle49@t-online.de

Key Words: microRNA-based therapy, target identification, HIF- $2 \alpha$, hypoxia-inducible factor $2 \alpha$, mTOR, mechanistic target of rapamycin, SPOP, speckle-type POZ protein, VEGF pathway, VHL, von Hippel Lindau tumor suppressor, review. tubules and can be classified into clear cell renal carcinoma (ccRCC), or of papillary or chromophobe subtype (2). In this review we focus on $\mathrm{ccRCC}$, the most common subtype with a prevalence between 80 and $90 \%$ of all RCCs (3). Localized primary tumors can be cured by surgical resection, however, the majority of renal cancers have already metastasized to the lungs, liver, bones and brain via the bloodstream or the lymphatics at the time of diagnosis (4). An early event in the pathogenesis of ccRCC is the mutational inactivation of von Hippel-Lindau tumor suppressor (VHL), the substrate recognition component of an E3 ligase complex that ubiquitinylates hypoxia inducible factors (HIF)- $1 \alpha$ and (HIF)-2 $\alpha$ for proteasome-mediated degradation (5). These transcription factors accumulate due to inactivation of VHL and induce vascular endothelial growth factor (VEGF). Therefore, ccRCCs are highly vascularized and respond to anti-angiogenic therapy. In addition, loss of chromosome $3 p$, driver gene mutations in the mechanistic target of rapamycin (mTOR) pathway and genes involved in epigenetic modification and chromatin remodeling such as AT-rich interactive domain-containing protein 1A (ARID-1A), BRCA associated protein 1 (BAP1), lysine-specific demethylase 5C (KDM5C), protein polybromo 1 (PBRM1) and histone methyltransferase SET domain containing 2 (SETD2) have been observed (6). A further characteristic of ccRCC is profound heterogeneity. An individual tumor can contain several evolving subclones with different driver mutations (2). Several anti-angiogenic agents such as the anti-VEGF monoclonal antibody (mAb) bevacizumab and tyrosine kinase inhibitors such as sorafenib, sunitinib, pazopanib, axitinib, levatinib as well as mTOR inhibitors such as temsirolimus and everolimus have been approved for treatment of metastatic disease (7). Immune-checkpoint inhibitors such as nivolumab [anti-programmed cell death protein 1 (PD1)] and a combination beween nivolumab and ipilimumab [anti-cytotoxic T-lymphocyte associated protein 4 (CTLA4)] were approved for treatment of advanced disease (8). However, the therapeutic benefit is hampered by 
development of resistance to the corresponding therapies. Therefore, identification of new targets and treatment modalities for ccRCC is an important issue. In this review we focus on up- and down-regulated microRNAs (miRs) and corresponding targets with in vivo efficacy in preclinical ccRCC-related systems.

\section{microRNA and Cancer}

miRs are transcribed from approximately 1,000 genes in the human genome by RNA polymerase II as precursors, transported into the cytoplasm and processed $(9,10)$. One strand of a 22 nucleotide (nt) duplex is maintained (guide strand), while the other strand (passenger strand) is degraded $(9,10)$. Binding of the guide strand to the 3 'untranslated region (3'-UTR) of the corresponding mRNA leads to degradation or translational repression of the target mRNA $(9,10)$. A single miR can interfere with several mRNAs and a single mRNA can be targeted by several miRs (11). Therefore, miRs can potentially modulate pathways at different levels and interfere with several pathways simultaneously and have the potential to rewire oncogenic pathways; however, collateral effects due to the modulation of non-oncogenic cellular pathways is a critical issue (12). miRs can exert tumor-suppressive and oncogenic functions and their ability to modulate different genes can be context-dependent. In addition, non-canonical functions of miRs such as agonizing of toll-like receptors 7 and 8 (TLR7, 8) have been described (13). This interaction can lead to promotion of tumor growth and metastasis by induction of inflammatory responses (13). miRs play a role during all stages of tumor formation, interaction of the tumor with the tumor micro-environment (TME) and metastasis (14). We recently summarized the role of miRs in metastasis (15-21). Aberrant expression of miRs in cancer can be due to methylation of the promoters of the corresponding genes or due to dysregulation of the processing of their precursor RNAs (22). The tumorsuppressor function of miRs has been revealed by the demonstration that miR-16-1 and -15 a prevent $\mathrm{B}-$ cell chronic lymphatic leukemia (B-CLL) in mice due to cleavage of anti-apoptotic protein B-cell lymphoma-2 (BCL-2) (23). The oncogenic role of miRs was shown by induction of hepatocellular carcinoma in transgenic mice by liver-specific expression of miR-221 (24).

\section{Up-regulated microRNAs}

microRNAs targeting transmembrane receptors

Up-regulation of adhesion molecules can inhibit tumor growth and metastasis of ccRCC cells and increased expression of corresponding miRs can counteract these functions.
miR-146a (CADM2). miR-146a (Figure 1A) is induced by hypoxia and high expression correlates with low survival rate in ccRCC patients (25). Over-expression of miR-146a promotes ACHN RCC cell proliferation and tumor growth in vivo in nude mice, whereas its decrease inhibits proliferation and invasion of 786-O RCC cells (25). As a target, the cell adhesion molecule M2 (CADM2) has been identified (25). Transfection of ACHN cells with miR-146a cells promotes growth (25). miR-146a also induces epithelial mesenchymal transition (EMT) of RCC cells (25). CADM2 is a member of the synaptic cell adhesion family of transmembrane receptors, has three Ig-like domains, promotes cell aggregation by homo- and heterophilic interactions with other nectin-like family members and organizes the function of synapses through heterophilic interactions (26). CADM2 increases the level of E-cadherin and decreases the levels of vimentin (VM) (25). CADM2 exhibits tumor supressor functions. Aberrant methylation and loss of expression of CADM2 has been observed during ccRCC tumor progression (27).

miR-720 (E-Cadherin). miR-720 (Figure 1A) is highly expressed in ccRCC and is a potential marker for diagnosis and prediction of survival in ccRCC patients (28). Depletion of miR-720 impairs migration, invasion, EMT and causes apoptosis in 786-O and A498 RCC cells (28). Intratumoral delivery of anti-miR-720 suppresses tumor growth of 786-O and A498 ccRCC xenografts (28). $\alpha$ E-catenin and Ecadherin have been identified as direct targets of miR-720 (28). Negative regulation of E-cadherin and $\alpha E$-cadherin causes EMT and metastasis (28). Reduced expression of Ecadherin facilitates ccRCC progression by activation of $\mathrm{WNT} / \beta$-catenin signaling (29). Low expression of $\mathrm{E}$ cadherin correlates with poor prognosis in patients with $\operatorname{ccRCC}(30,31)$.

\section{microRNAS targeting signalling-related proteins}

miRs targeting tumor suppressors or inhibitors of signaling pathways can increase proliferation, migration and invasion of ccRCC cells.

miR-21 (PTEN, PTENP1). miR-21 (Figure 1A) targets the phosphatase and tensin homolog (PTEN) and PTENP1, a pseudogene of PTEN $(32,33)$. In vitro, PTENP1 suppresses migration and invasion of ACHN and SN12PM6 RCC cells (32). miR-21 promotes tumor growth and metastasis of ACHN cells in vivo. In line with this, PTENP1 and PTEN inhibit tumor growth and metastasis in nude mice (32). PTENP1 RNA competes for regulation of PTEN expression by miR-21 (32). PTEN also attenuates phosphoinosite 3kinase $(\mathrm{PI} 3 \mathrm{~K}) / \mathrm{AKT} / \mathrm{mTOR}$ signaling through its lipid phosphatase activity (34). PTENP1 is deleted in melanoma and non-small cell lung carcinoma (NSCLC) $(35,36)$ while 
A

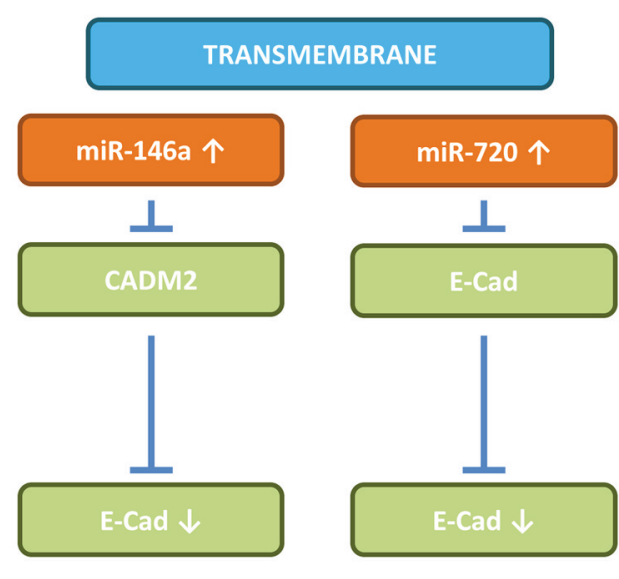

B

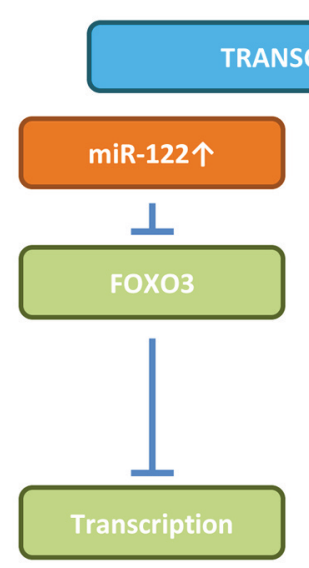

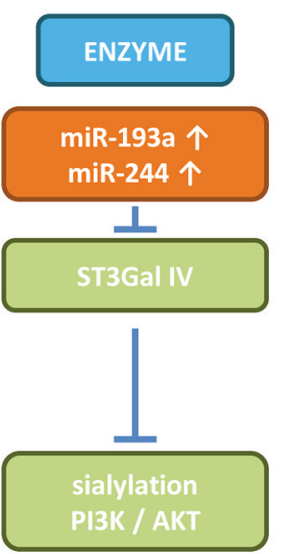

SIGNALING

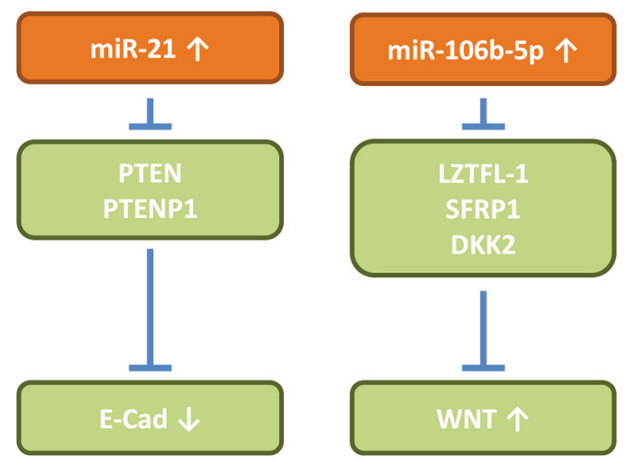

Figure 1. Up-regulated microRNAs mediating efficacy in kidney-cancer related in vivo models. miRs, targets and corresponding effectors are shown. (A) miRs with transmembrane receptors and signaling-related proteins as targets. (B) miRs covering transcription-related targets, enzymes and other targets. CADM2: Cell adhesion molecule 2; DKK2: dickkopf-related protein 2; E-Cad: E-cadherin; LZTFL1: leucine zipper transcription factor like 1; mTOR: mechanistic target of rapamycin; PTEN: phosphatase and tensin homolog; PTENP1: pseudogene 1 of PTEN; SFRP1: secreted frizzled-related protein 1; WNT: WNT signaling; AKT: ser-thr kinase AKT; ARID-1A: AT-rich interactive domain-containing protein 1A; DICER: endoribonuclease DICER; FOXO3: forkhead box O3; PI3K: phosphoinosite 3-kinase; ST3Gal IV: a 2,3 sialyltransferase IV; SWI/SNF: SWI/sucrose non fermentable.

low PTEN is significantly associated with unfavorable outcome in ccRCC patients (37).

miR-106-5p (WNT signaling). High expression of miR-106$5 \mathrm{p}$ (Figure 1A) predicts poor survival of ccRCC patients (38). miR-106-5p induces markers of stemness in Caki-1 RCC cells (38). This miRNA targets the leucine zipper transcription factor like 1 (LZTFL1), secreted frizzledrelated protein 1 (SFRP1) and dickkopf-related protein 2 (DKK2), all inhibitors of WNT signaling (38). miR-106 promotes growth of Caki-1 cells after implantation into the renal capsule and lung metastasis after tail vein injection into nude mice (38). In line with this, WNT signaling has been shown to promote proliferation, migration and invasion in $\operatorname{ccRCC}(39,40)$

microRNAs targeting transcription-related proteins

Transcription factors can exert an inhibitory as well as an activating function on proliferation, invasion and migration of ccRCC cells. The function of inhibitory transcription factors can be reversed by up-regulation of the corresponding miRs.

miR-122 (FOXO3). High expression of miR-122 (Figure 1B) correlates with reduced metastasis-free survival in ccRCC patients (41). This miRNA targets transcription factor forkhead box O3 (FOXO3) and promotes proliferation, 
invasion and EMT of 786-0 and SN12-PM6 RCC cells (41). FOXO3 has been shown to inhibit proliferation, tumorigenic potential and invasiveness of cancer cells $(42,43)$. In ccRCC, FOXO3 promotes tumor metastasis and is associated with metastasis-free survival in patients (44).

miR-144-3p (ARID-1A). miR-144-3p (Figure 1B) promotes proliferation, invasion and clonogenicity of 786-O and SN12-PM6 RCC cells (45). An AT-rich interaction domaincontaining protein 1A (ARID-1A) has been identified as a direct target of miR-144-3p (45). The latter promotes tumor formation of SN12PM6 RCC cells in vivo (45). ARID-1A is a key member of the switch/sucrose non-fermentable (SWI/SNF) chromatin-modeling complex which functions as a negative regulator in cell cycle, apoptosis and tumorigenicity $(46,47)$. The target protein also triggers EMT of renal cells (48). Decreased ARID-1 A expression correlates with poor prognosis of ccRCC (49) while mutations in this gene have been noted in up to $12 \%$ of ccRCCs and protein loss has been observed in $50 \%$ of ccRCCs $(50,51)$. In ccRCC with mutated ARID-1A, dramatically lower levels of CD8+ T-cell infiltrates have been observed, compared with those without ARID-1A mutations.This suggests that the ARID-1A mutation status can be a predictive biomarker for immune-checkpoint therapy of ccRCC (52).

\section{microRNAs targeting enzymes}

A miR targeting a glycosylation-related enzyme can mediate proliferation, migration and invasion of ccRCC cells.

miR-193a, miR-224 (ST3Gal IV). Over-expression of miR193a and miR-224 (Figure 1B) increases RCC proliferation and migration both in vitro and in vivo (53). $\alpha 2,3$ sialyltransferase IV (ST3GalIV) enzymatic activity has been identified as a direct target of these miRs (53). Downregulation of ST3GalIV correlates with induction of PI3K/AKT signaling (53). ST3GalIV is highly expressed in adjacent normal tissues (53). Sialyltransferases add sialic acid to nascent oligosaccharides and each sialyltransferase is specific for a particular sugar substrate $(54,55)$. Sialylation is involved in cell fate decisions and cancer progression and aberrant glycosylation is a new hallmark of cancer (56). ST3GalIV enzymatic activity has been found in several types of cancer $(57,58)$. However, how down-regulation of ST3GalIV mediates ccRCC pathogenesis still remains to be resolved.

microRNAs targeting other proteins

A miR targeting a component of the miR-processing pathway has an impact on metastasis of ccRCC cells.

miR-122 (DICER). miR-122 (Figure 1B) levels are upregulated in ccRCC and increased levels are associated with
ccRCC metastasis (59). DICER has been identified as a direct target of miR-122 (35). The latter promotes migration, invasion and EMT of OS-RC-2 RCC cells by downregulation of DICER (59). miR-122 promotes lung metastasis of OS-RC2 cells after tail vein injection in nude mice (59). Its overexpression down-regulates miR-200 family members in OS-RC-2 cells indicating a new feedback loop in which miR-122 may function as a key miR to control various mature metastasis-related miRs through DICER modulation. DICER belongs to the RNAse III family of double-stranded RNAses which control maturation of miRs in the cytoplasm (60). It is down-regulated in ccRCC while, in vitro, DICER knockdown enhances invasive phenotype formation (61). In VHL-deficient RCC cells, DICER suppresses the invasive phenotype by inhibiting HIF-2 $\alpha$ (62).

\section{Down-regulated miRs}

microRNAs targeting transmembrane receptors. Transmembrane proteins located in the plasma membrane or in the membrane of intra-cellular organelles, can accelerate growth and invasion of ccRCC cells through activation of signal transduction pathways. This can be accomplished by down-regulation of the corresponding miRs.

$m i R-137$ (RLIP76). miR-137 (Figure 2) is significantly downregulated in ccRCC tissues in comparison to corresponding non-cancerous tissues (63). Ectopic expression decreases proliferation, invasion and induces apoptosis in RCC cells (63). This miRNA inhibits pulmonary metastasis of ccRCC cells after tail vein injection into nude mice (63). Ral interacting protein of $76 \mathrm{kD}$ (RLIP76) has been identified as a direct target of miR-137 (63). RLIP76 is a multifactorial protein with transport and signaling functions. It contains a surface domain (171 to 186 amino acids) but its membrane topology is not yet resolved (64). Transport of glutathioneconjugates is a documented function of RLIP76 (64). Blocking the transport function of RLIP76 causes regression of RCC xenografts in nude mice (65). Similarly, depletion of RLIP76 leads to reduced activation of survival pathways such as PI3K, extracellular signal-regulated kinase (ERK) and AKT. Therefore, RLIP76 emerges as an important therapeutic target for ccRCC $(66,67)$.

miR-141 (EPH2). miR-141 (Figure 2) is decreased in ccRCC tissues in comparison to corresponding normal tissues (68). Overexpression of $\mathrm{miR}-141$ attenuates proliferation and motility of 786-O and SN12-PM6 RCC cell lines (68). In an orthotopic RCC xenograft model, miR-141 suppressed tumorigenesis and metastasis to the liver, lungs, lymph nodes and peritoneum (68). Erythropoietin-producing human hepatocellular receptor A2 (EPHA2) was identified as a direct target of this miRNA (68). EPHA2 is frequently up-regulated 


\section{TRANSMEMBRANE RECPTORS}
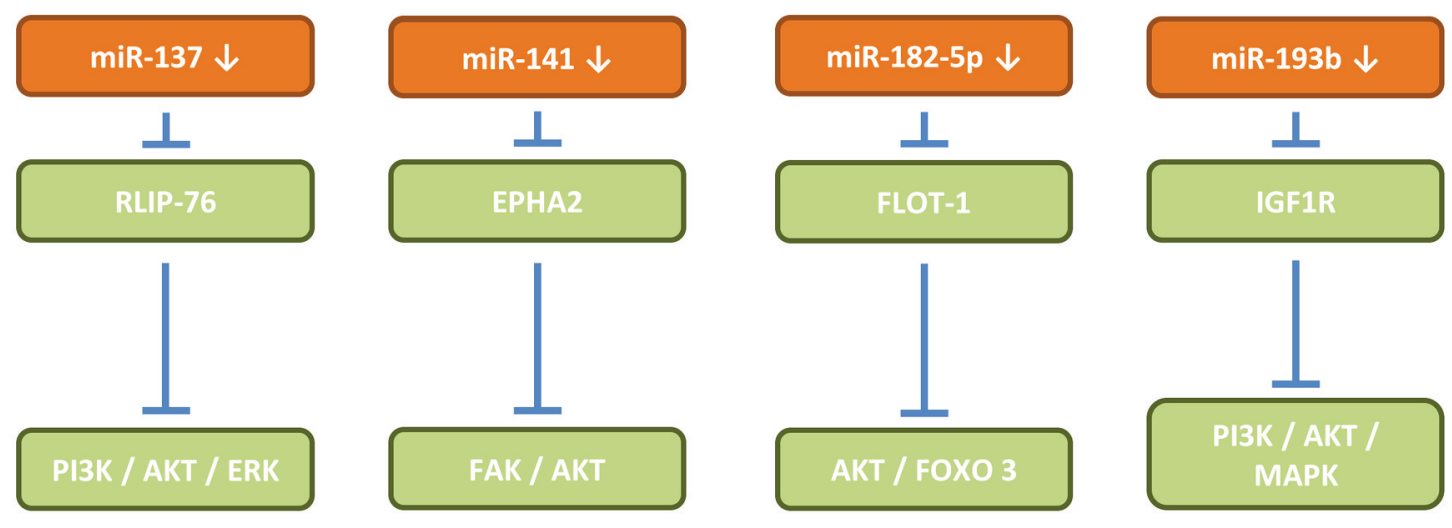

Figure 2. Down-regulated miRs targeting transmembrane receptors with efficacy in preclinical kidney cancer-related in vivo systems. AKT: Ser-thr kinase AKT; EPHA2: erythropoietin-producing human hepatocellular receptor A2; ERK: extracellular signal-regulated kinase; FAK: focal adhesion kinase; FLOT-1: flotilin 1; FOXO3: forkhead box 3; IGF1R: insulin growth factor 1 receptor; PI3K: phosphoinositide 3-kinase; MAPK: mitogenactivated protein kinase; RLIP76: Ral interaction protein of $76 D$.

in ccRCC and activates focal adhesion kinase (FAK) and AKT signaling (68) while its expression in tumor tissues predicts locally aggressive behaviour and poor outcome in patients with ccRCC (69). Accumulation of EPHA2 modulates cytoskeleton dynamics, loss of cell contact, proliferation, oncogenic signaling and metastasis $(70,71)$. Multiple drugs targeting EPHA2 are under preclinical and clinical development in several types of cancer (72).

miR-182-5p (FLOT-1). miR-182-5p (Figure 2) is downregulated in ccRCC and inhibits proliferation and tumorigenicity of 786-O and Caki-1 RCC cells in vitro and in vivo (73). Upregulation of miR-182 leads to $\mathrm{G} 1$ phase arrest, inhibition of AKT signaling and induction of transcription factor FOXO3 (11). Flotilin 1 (FLOT-1) was identified as a target of miR-182-5p (73). FLOT-1 is a caveolae-associated integral membrane protein which tethers membrane receptors and acts as a signaling molecule (74, 75). Flotilin-1 oligomer-based microdomain scaffolds are involved in molecular sorting, endocytic pathways, phagosomal trafficking and coordinate a variety of signaling processes (76). FLOT-1 plays a role in the progression of several types of carcinomas (76).

$m i R-193 b$ (IGF1R). Expression of miR-193b (Figure 2) is decreased in ccRCC tissues in comparison to matched normal tissues (77). miR-193b inhibits proliferation, invasion and migration of Caki-1 RCC cells in vitro and tumor growth in vivo in nude mice (77). Insulin-like growth factor receptor 1 (IGFR1) has been identified as a target of miR-193b (77). IGFR1 promotes malignant transformation, induces proliferation, but inhibits apoptosis in ccRCC $(78,79)$. Several IGFR1 inhibitors are undergoing clinical trials in several types of carcinomas (80).

microRNAs targeting signaling-related proteins

Tumor growth and metastasis can be mediated by activation of growth factors, transcription factors, ser-thr and tyrosine kinases, GTPases and nuclear receptors. This can be achieved by down-regulation of miRs targeting these components.

miR-28-5p (RAP1B). miR-28-5p (Figure 3A) is downregulated in ccRCC in comparison to corresponding normal tissues (81). miR-28-5p suppresses proliferation of A498 and ACHN RCC cells in vitro and tumor growth in vivo in nude mice through targeting ras-related protein 1B (RAP1B) (81). miR-28-5p represses mitogen activated protein kinase (MAPK) signaling by inhibiting phosphorylation of p38 mitogen-activated kinase (p38) and ERK1/2 (81). As a physiological function, RAP1B GTPase is involved in platelet activation/adhesiveness after injury (82). In cancer, RAP1B activates multiple signaling pathways associated with tumor cell proliferation, invasion, cell adhesion and angiogenesis $(83,84)$.

miR-99a (mTOR). miR-99a (Figure 3A) is down-regulated in ccRCC and correlates with overall survival (85). In 786-O and OS-RC-2 RCC cells, miR-99a inhibits proliferation, induces $\mathrm{G} 1$ phase cell-cycle arrest and inhibits migration and invasion (85). In vivo, miR-99a suppresses tumor growth of 786-O xenografts in nude mice (85). mTOR has been identified as a target of miR-99a (85). mTOR knock-down 
partially phenocopies miR-99a restoration in RCC cells (85). mTOR signaling links multiple receptors and oncogenes to cell growth, protein translation, metabolism, cell invasion and cell-cycle via downstream effectors such as $\mathrm{p} 70$ ribosomal protein S6 kinase (p70S6K) and eukaryotic translation initiation factor 4E- binding protein 1 (4E-BP1) $(86,87)$. mTOR inhibitors temsirolimus and afinitor, both rapamycin analogues, have been approved for treatment of ccRCC (88-90).

miR-106a-5p (PAK5). miR-106a-5p (Figure 3A) is downregulated in ccRCC in comparison to correspondng normal tissues (91). In 786-O and ACHN RCC cells, miR-106-5p inhibits migration and invasion by targeting p21 activated protein kinase (PAK5) (91). In an experimental metastasis model, miR-106a-5p suppresses metastasis to the lungs in nude mice (91). PAK5 is member of a family of six isoform versions which play a role in cytoskeletal dynamics, cell survival and proliferation. They are overexpressed, hyperactivated or amplified in several types of cancer and function as signal transducers in pathways such as RAS, RAF, nuclear factor $\mathrm{kB}$ (NFkB), AKT and protein 53 (p53) (92). PAK5 can act as an oncogene as well as an effector of GTPases ras-related C3 botulinum toxin substrate (RAC) and cell division control protein 42 homolog (CDC42) and is presently under validation as a target for cancer therapy $(93,94)$.

$m i R-143,-216 b$ (KRAS). miR-143 and -216b target kirsten rat sarcoma viral oncogene homolog (KRAS). miR-143 (Figure 3A) is down-regulated in ccRCC tissues, compared to corresponding normal tissues (94). A synthetic version miR-143 inhibits growth of Caki-1 ccRCC cells in vitro and tumor growth in vivo after systemic polyion complex-based delivery in nude mice (94). miR-143 perturbs cancer specific energy metabolism and induces autophagy (94). A partial metabolic shift from glycolysis to oxidative phosphorylation has been observed. miR-143 down-regulates glucose transporter 1 (GLUT1) and also suppresses PI3K/AKT and MAPK/ERK signaling.

miR-216b (Figure 3A) is down-regulated in ccRCC specimens, in comparison to corresponding normal tissues. It suppresses proliferation and invasion of 786-O and ACHN RCC cell lines and inhibits tumor growth of ACHN ccRCCbased xenografts in vivo (95). It also interferes with $\mathrm{AKT}$ and ERK pathways (95).

KRAS functions as a small GTPase and transduces signals from cell surface receptors to the cytoplasm through specific effector pathways such as MAPK/ERK and PI3K/AKT, while regulating diverse cellular responses $(96,97)$. KRAS is involved in ERK1/2-based phosphorylation and nuclear translocation of pyruvate kinase muscle isoform 2 (PKM2) promoting the Warburg effect (98). Due to its de-regulation in many types of cancer, KRAS is an important target, however its druggability is a critical issue (99, 100). Recently significant progress has been achieved in the treatment of KRAS mutated tumors (101). In ccRCC, KRAS mutations rarely occur, however, de-regulation of KRAS signaling is a frequent event (102).

$m i R-148 a(A K T 2)$. miR-148a (Figure 3A) is down-regulated in ccRCC cell lines and tissues and its down-regulation is associated with lymph node metastasis (103). miR-148a inhibits proliferation, colony formation and migration of 786-O ccRCC cells via suppression of AKT2 (103). Tumor growth in nude mice from 786-O cells transfected with miR$148 \mathrm{a}$ is attenuated (103). AKT2 is an isoform of the AKT2 family which functions as an oncogene by enhancing survival, migration and invasion of cancer cells. This gene is a member of the PI3K/AKT pathway and phosphorylates downstream targets including mTOR (104, 105). Independently it was shown that AKT2 is de-regulated in ccRCC (106). mTOR inhibitors everolimus and temsirolimus are approved for treatment of ccRCC (107).

$m i R-205-5 p$ (VEGF). Expression of miR-205-5p (Figure 3B) is down-regulated in ccRCC and correlates with poor prognosis of patients (108). miR-205-5p inhibits proliferation, migration, EMT and induces apoptosis of 786$\mathrm{O}$ and ACHN ccRCC cells (108). VEGF-A was identified as a direct target of miR-205-5p (108). This miRNA inactivates the PI3K/AKT/mTOR signaling pathway (108). 786-O xenografts in nude mice expressing miR-205-5p exhibit decreased tumor growth (108). The VEGF pathway plays an important role in ccRCC (109). The VEGF inhibitors sorafenib, sunitinib, bevacizumab, pazopanib, cabozantinib and axitinib are approved for treatment of $\operatorname{ccRCC}(110,111)$.

miR-30a-3p, -30c-2-3p, -145 (HIF-2 $\alpha$ ). Reduced expression of miR-30a-3p and miR-30c-2-3p (Figure 3B) was significantly associated with poor prognosis in patients with ccRCC (112). Both target hypoxia-inducible factor $2 \alpha$ (HIF$2 \alpha$ ) directly (112). In vivo, tumor growth of UMRC2 xenografts is inhibited by both miRs (112). miR-30a-3p and miR-30c-2-3p repression enhance HIF- $2 \alpha$ expression, a mechanism whereby the tumor-suppressive effect of constitutive HIF-1 $\alpha$ expression is attenuated in HIF $1 \alpha / \mathrm{HIF} 2 \alpha$ tumors. Under high oxygen conditions, HIF1 $\alpha$ and HIF2 $\alpha$ are hydroxylated by prolylhydroxylase enzymes, resulting in VHL recognition, polyubiquitinylation and subsequent proteasomal degradation (113). Under low oxygen conditions, HIF- $2 \alpha$ subunits are stabilized and activate numerous genes involved in metabolism, angiogenesis, motility/invasion and extracellular matrix (ECM) remodeling (114). HIF-1 $\alpha$ acts as a TS, whereas HIF- $2 \alpha$ promotes tumorigenesis $(115,116)$. Restricted expression of miR-30a-3p and miR-30c-2-3p in ccRCC enhances HIF- $2 \alpha$ activity. 
A

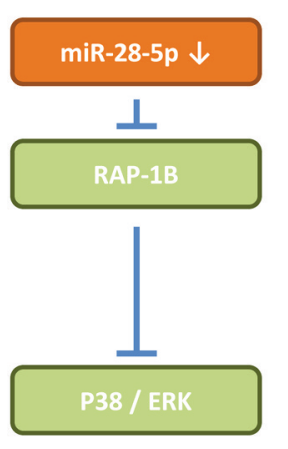

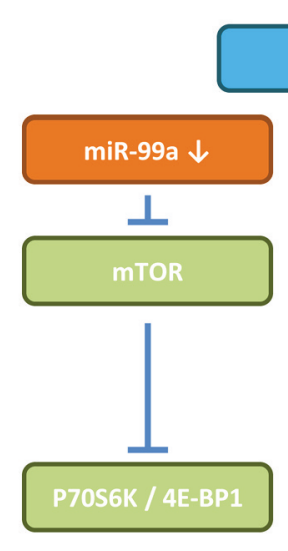
SIGNALING-RELATED TARGETS

B
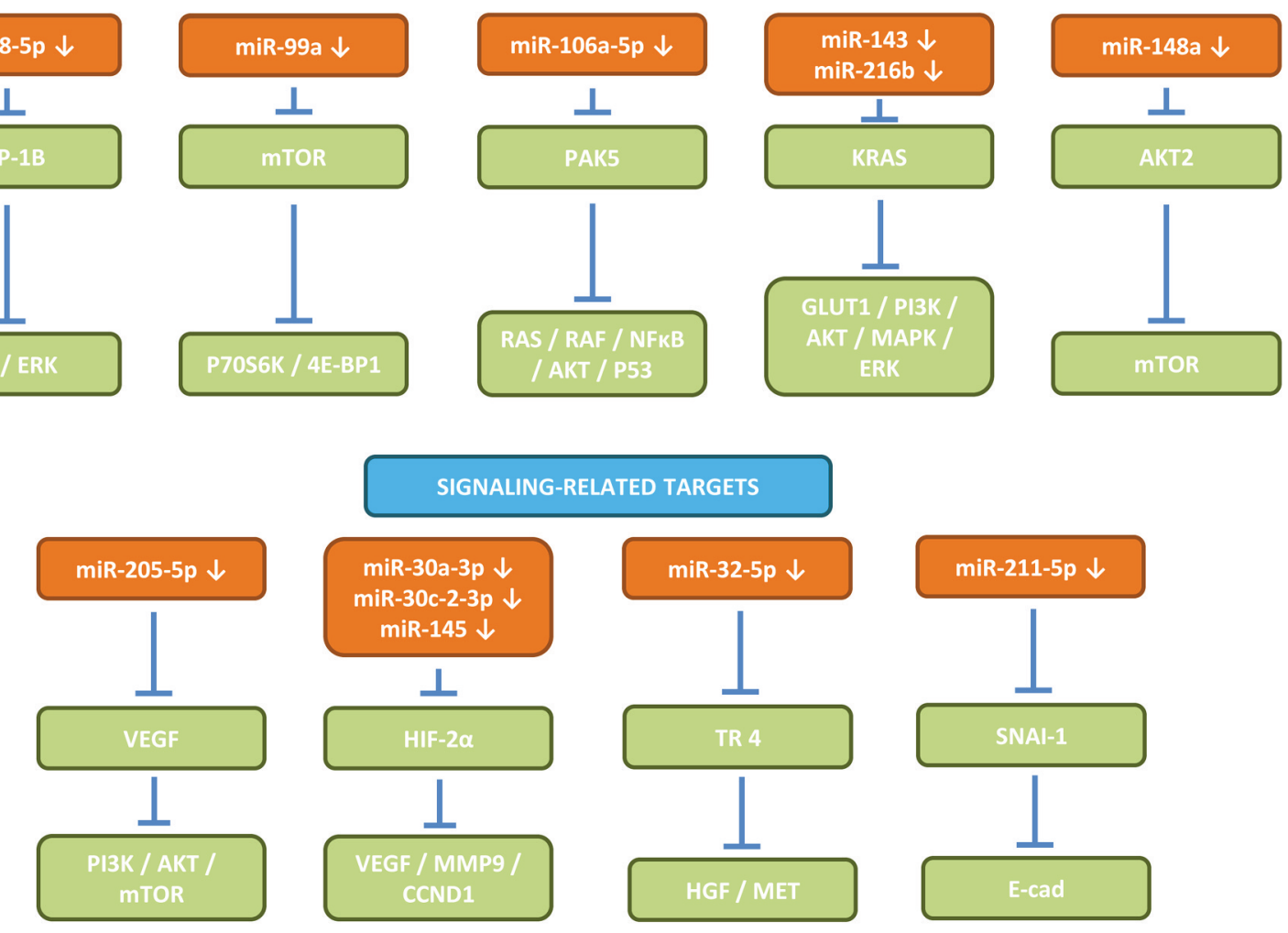

Figure 3. Down-regulated miRs targeting signaling-related proteins with efficacy in preclinical kidney cancer-related in vivo systems. 4 E-BP1: Eukaryotic translation initiation factor (eIF4E) binding protein 1; AKT2: ser-thr kinase AKT2; ERK: extracellular signal regulated kinase; GLUT1: glucose transporter 1; KRAS: Kirsten rat sarcoma viral oncogene homolog; MAPK: mitogen-activated protein kinase; mTOR: mechanistic target of rapamycin; NFkB: nuclear factor kB; p38: 38 mitogen-activated kinase; p53: protein 53; p70S6K: p70 ribosomal protein S6 kinase; PAK5: p21 activated protein kinase 5; RAP-1B: ras-related protein 1B; AKT: ser-thr kinase AKT; CCND1: cyclin D1; HGF: hepatocyte growth factor; HIF-2 $\alpha$ : hypoxia-inducible factor 2 $\alpha$; MET: transmembrane tyrosine kinase receptor MET; p19ARF: ARF tumor suppressor p19; PI3K: phosphoinositide 3-kinase; SNAI-1: zinc finger protein SNAI-1; TR4: testicular nuclear receptor 4; VEGF: vascular endothelial growth factor; ZBTB7A: zinc finger and BTB domain containing protein 7.

Androgen receptor (AR) down-regulates miR-145 (Figure 3B) via promoter interaction in ccRCC cell lines (117). miR145 inhibits proliferation and invasion of OS-RC2 (VHL wildtype) and SW-839 (VHL inactivating mutant) RCC cells (117). miR-145 targets HIF-2 $\alpha$ and suppresses HIF2 $\alpha /$ VEGF/matrix metalloproteinase 9 (MMP9) / cyclin D1 (CCND1) signals in OS-RC2 and SW-839 ccRCC cell lines (117). In an orthotopic kidney capsule model, miR-145 suppresses tumor growth and metastasis of OS-RC2 cells (117). ccRCC patients with higher $\mathrm{AR}$ expression had lower overall survival rates, linking $\mathrm{AR}$ to poor prognosis (118). AR in ccRCC cells increases proliferation and AR inhibitors enzalutamide and abiraterone inhibit TG of Caki-1 xenografts in nude mice (119). Intracrine androgen biosynthesis has been observed in ccRCC and AR increases hematogenous metastasis of ccRCC (120).
miR-32-5p (TR4). miR-32-5p (Figure 3B) is down-regulated in ccRCC tissues of patients with distant metastases compared to those from metastasis-free patients (121). miR32-5p inhibits invasion of ACHN, SW839 and OS-RC2 ccRCC cells by targeting testicular nuclear receptor 4 (TR4) (121). After implantation into the renal capsule, miR-32-5p inhibits metastasis of OS-RC2 xenografts into the lungs, spleen and liver (121). In this experimental system, sunitinib suppresses metastasis via induction of miR-32-5p and suppression of TR4 (121). miR-32-5p attenuates metastasis through interference with TR4/fibroblast growth factor (FGF)/MET signaling (121). TR4 is an orphan receptor of the family of steroid receptor transcription factors $(122,123)$. This receptor can alter hepatocyte growth factor (HGF)/MET signaling by binding to the TR4-response element of the 
HGF promoter (121). Inhibition of the HGF/MET pathway is actively pursued in patients with ccRCC (124).

miR-211-5p (SNAI-1). miR-211-5p (Figure 3B) suppresses migration and invasion of RCC cells A498 and 786-O through targeting SNAI-1 family transcriptional repressor 1 (SNAI-1) (125). In an orthotopic model, miR-211-5p inhibits tumor growth and metastasis of A498 RCC cells to the lungs, spleen and liver (125). SNAI-1 is a zinc finger transcription factor which induces EMT by down-regulation of Ecadherin. It also regulates cell morphology and cell-cell interactions $(126,127)$. In ccRCC, SNAI-1 is a marker of progression-free and overall survival (128).

\section{micro-RNAs targeting cell cycle-related proteins}

Multiple functions of miRs regulating the cell cycle have been documented. In addition to targeting components of the cell-cycle (129), they can regulate DNA damage response (130), licensing of DNA replication (131), modulation of activity of DNA replication inhibitor geminin, retinoic acid signaling and pluripotency (132).

miR-1 targets CDK4, CDK6, Caprin 1 and SLUG. miR-1 (Figure 4A) down-regulation correlates with clinicopathological characteristics and overall survival of ccRCC patients (133). miR-1 inhibits proliferation, migration and invasion of 786-O ccRCC cells (133). It targets cyclindependent kinases 4 and $6(\mathrm{CDK} 4,6)$, caprin 1 and metastasis related gene SLUG (SNAI-2) (133). In vivo, miR1 inhibits tumor growth of ACHN-derived xenografts after sucutaneous and orthotopic implantation in nude mice (133). CDK4 and CDK6 inhibitors such as palbociclib, ribociclib and abemaciclib have been approved for hormone-sensitive, human epidermal growth factor receptor 2 (HER2) negative breast cancer (134). The other target, caprin-1, is a mediator of proliferation and cell-cycle progression (135). Target SLUG (SNAI-2) is a zinc finger-based transcriptional repressor which is involved in EMT and mediates antiapoptotic activity $(136,137)$.

miR-200c targets CDK2. miR-200c (Figure 4A) is downregulated in ccRCC specimens (138). In SN12-PM6 and 786-O cells, this miRNA suppresses proliferation and induces cell-cycle arrest (138). Cyclin-dependent kinase 2 (CDK2) has been identified as a direct target of miR-200c (138). In orthotopic xenografts, miR-200c suppresses growth of SN12-PM6 RCC cells (138). Deregulation of CDK2 is associated with several types of cancer, however, it is dispensable for normal development (139). In addition to its involvment in cell-cycle progression, miR-200c mediates DNA-damage repair, DNA and RNA metabolism and signal transduction (139). Several CDK2 inhibitors are evaluated in clinical studies, however it emerged that due to pronounced toxicity effects, more selective inhibitors need to be evaluated (140). In ccRCC, CDK2 is a strong predictor of recurrence (141).

miR-206c targets $C D K 4,9$, and CCND1. miR-206c (Figure 4A) inhibits proliferation of ccRCC cells through induction of cell-cycle arrest and tumor growth in subcutaneous and orthotopic ccRCC xenografts (142). CDK4, CDK9 and CCND1 have been identified as direct targets of miR-206c (142). As already outlined, CDK4 is a validated target for treatment of hormone receptor positive, HER2-negative metastatic breast cancer (143). CDK9 is a serine-threonine kinase which is involved in DNA transcription by phosphorylating RNA polymerase II and several transcription factors (144). However, more selective inhibitors of CDK9 have to be generated to explore their therapeutic potential (144). CCND1 is involved in cell-cycle transition to the S-phase by activating cyclin-dependent enzymes $(145,146)$.

microRNAs targeting components of the extracellular matrix Components of the ECM such as laminins and collagens have a positive impact on angiogenesis and metastasis of ccRCC cells. This can be achieved by down-regulation of the corresponding miRs.

miR-200b targets LAMA4. miR-200b (Figure 4B) expression inversely correlates with survival in patients with ccRCC (147). miR-200c impedes cell spreading and migration, but not growth, in ccRCC cell lines OS-RC2 and Caki-1 (147). Laminin subunit $\alpha 4$ (LAMA4) has been identified as a direct target of miR-200b (147). In vivo, miR-200b has no impact on proliferation, but inhibits metastatic colonies in the lungs after tail vein injection in nude mice (147). LAMA4 is an ECM glycoprotein and is part of the laminin complex. It is secreted into the ECM, up-regulates integrin $\alpha 5 \beta 1$ and activates the integrin-linked kinase (ILK)/FAK/ERK pathway (148). $\alpha 4$ chain laminins are widely expressed in ccRCC and have a de-adhesive function (148). LAMA4 promotes angiogenesis and is enriched in blood vessels of ccRCC patients while its expression correlates with poor prognosis $(149,150)$. Intra-tumoral injection of miR-200b mimetics decreases lung metastasis in mice (147).

Let $7 d$ targets COL3A1. Decreased let-7d (Figure 4B) is associated with advanced tumor stages in ccRCC patients and is inversely correlated with macrophage infiltration (151). Over-expression of let-7d impedes growth and migration of 786-O and 769-P RCC cell lines in vitro (151). In vivo, in 786-O cell-derived xenografts, let-7d inhibits tumor growth (151). In patient-derived xenografts (PDX), intra-tumoral injection of let-7d mimetics inhibit tumor growth and metastatic nodules in the lungs of nude mice 


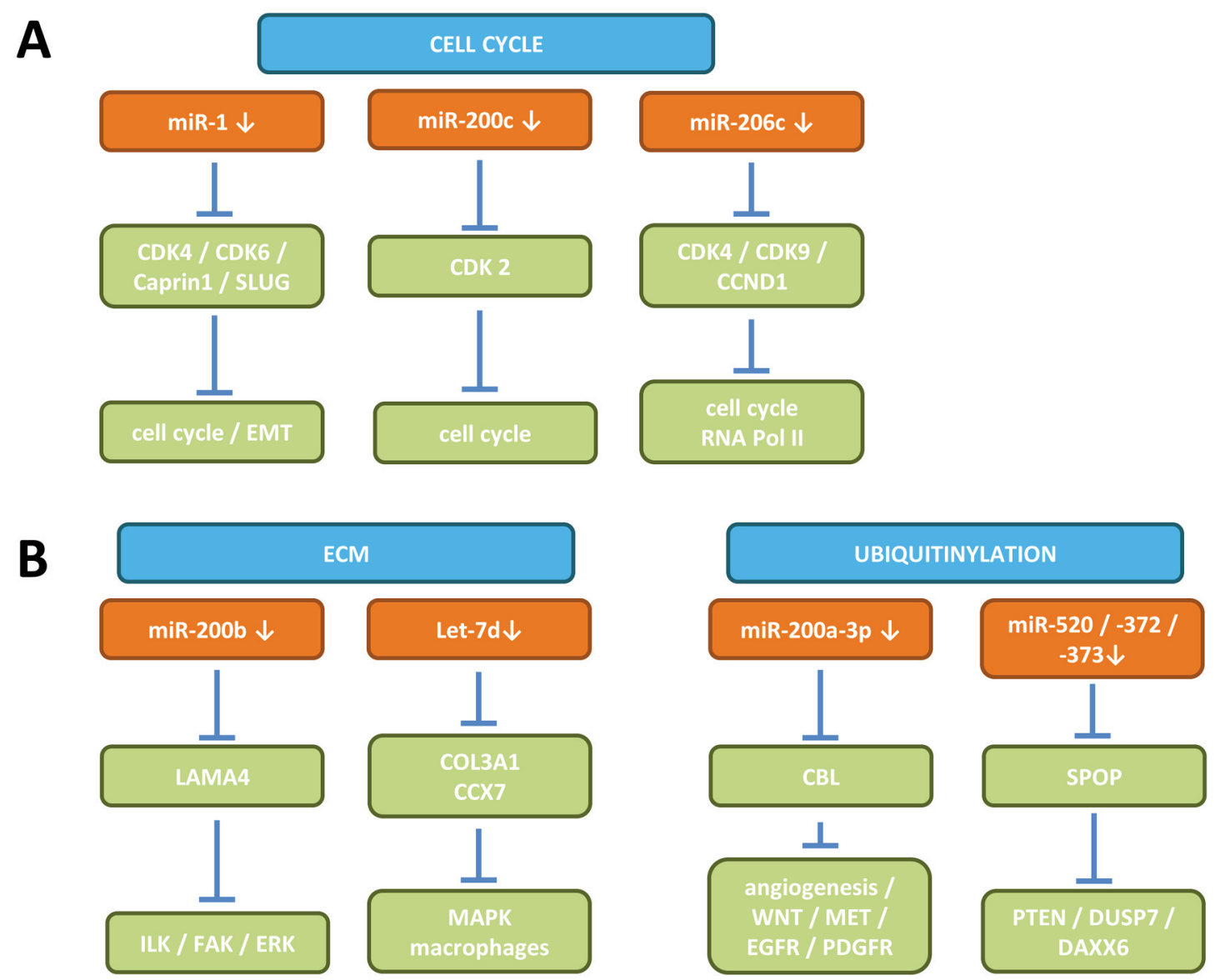

Figure 4. Down-regulated miRs targeting cell-cycle, extracellular matrix and ubiquitinylation related enzymes with efficacy in preclinical kidney cancer-related in vivo systems. (A) miRs targeting cell-cycle related proteins. (B) miRs targeting extracellular matrix and ubiquitinylation-related proteins. CDK2,4,6,9: Cyclin-dependent kinases 2,4,6,9; CCND1: cyclin D1; SLUG: transcription factor SLUG (SNAI-2); EMT: epithelial mesenchymal transition; RNA pol II: RNA polymerase II; CBL: Casitas B-lineage lymphoma; CCC7: chemokine (C-C motif) ligand 7; COL3A1: $\alpha 1$ chain of type III collagen, DAXX6: death-associated protein 6; DUSP7: dual specificity phosphatase 7; EGFR: epidermal growth factor receptor 7; ERK: extracellular signal-regulated kinase; FAK: focal adhesion kinase; ILK: integrin-linked kinase; LAMA4: laminin subunit 4; MAPK: mitogenactivated protein kinase; MET: transmembrane receptor tyrosine kinase MET; PDGFR: platelet-derived growth factor receptor; PTEN: phosphatase and tensin homolog; SPOP: speckle-type POZ protein.

(151). $\alpha 1$ chain of type III collagen (COL3A1) and chemokine (C-C motif) ligand 7 (CCL7) have been identified as direct targets of let-7d (151). Col3A1 is involved in ECM organization, cell adhesion, migration and invasion through the MAPK pathway (152). Col3A1 expression is correlated with a poor prognosis in patients with bladder cancer and ovarian carcinoma $(153,154)$. CCL7 promotes tumor growth by recruiting leukocytes including monocytes, macrophages and neutrophiles to the tumors facilitating TME formation, invasion and metastasis (155).

microRNAs targeting E3-ubiquitin-ligases

Ubiquitinylation marks proteins for degradation by the proteasome leading to deregulation of transcription factors and signaling components. This results in proliferation, migration and survival of tumor cells. Down-regulation of miRs targeting ubiquitinylation enzymes mediates protumoral effects in ccRCC cells.

miR-200a-3p targets CBL. miR-200a-3p (Figure 4B) is down-regulated in ccRCC tissue in comparison to normal adjacent tissue (156). miR-200a-3p suppresses proliferation and migration and enforces apoptosis in vitro and in vivo (152). Casitas B-lineage lymphoma (CBL) has been identified as a target for miR-200a-3p (156). CBL functions as an E3 ubiquitin-ligase and consists of an N-terminal tyrosine kinase binding domain, a ring finger domain, a proline rich domain which interacts with adaptor proteins 
and a C-terminal domain which binds ubiquitin (157). CBL is involved in survival, migration and proliferation (157). However, inhibition of angiogenesis has also been reported for CBL (158). Taken together, the role of CBL in ccRCC has to be resolved in further detail.

miR-520/372/373 target SPOP. In vitro miRs-520/372/373 (Figure 4B) suppress proliferation and migration in A498 and ACHN ccRCC cells (159). Tumor growth of ACHN xenografts is suppressed by each of these miRs (159). Speckle-type POZ protein (SPOP) has been identified as a target of these miRs (159). SPOP functions as an E3 ubiquitin ligase which is highly expressed in ccRCC $(160,161)$. It is transcriptionally activated by HIF-2 $\alpha$ and functions as a key hub in kidney cancer (162). It induces degradation of tumor suppressors such as PTEN and dual-specificity phosphatase (DUSP7), pro-apoptotic target death-associated protein 6 (DAXX6) and is part of a novel pathway in ccRCC (162). SPOP expression correlates with a bad prognosis in ccRCC (163). Small molecules have been identified which inhibit SPOP-substrate protein interaction and suppress oncogenic SPOP signaling pathways in ccRCC (164).

\section{microRNAs targeting apoptosis-related proteins}

Anti-apoptotic proteins are crucial for survival of tumor cells. This is achieved by down-regulation of miRs which inactivate mRNAs encoding anti-apoptotic enzymes.

miR-337-3p targets CAPN4. miR-337-3p (Figure 5A) is downregulated in ccRCC cell lines (165). It inhibits proliferation, colony growth and invasion, but enhances cell adhesion (165). Knock-down of miR-337-3p exerts the opposite effects (165). miR-337-3p inhibits EMT and suppresses growth of ccRCC xenografts in nude mice (165). Calpain small regulatory subunit 4 (CAPN4) was identified as a target of miR-337-3p (165). The calpain family of Ca-dependent non-lysosomal cysteine proteases is involved in proteolysis of many substrates, cytoskeletal remodeling, cell survival, apoptosis and cellular signaling. Proteins of the NFkB, FAK pathways and cMYC have been identified as targets of CAPN4-regulated enzymes $(166,167)$. The latter are also involved in metastasis (168). CAPN4 has been shown to be a poor prognostic factor in gastric carcinoma (169).

miR-708 targets c-FLIP. miR-708 (Figure 5A) inhibits proliferation and promotes apoptosis of Caki-1 ccRCC cells and attenuates tumor growth of xenografts in nude mice (170). Caspase flice-like inhibitory protein (c-FLIP) was identified as a target for miR-708 (170). c-FLIP acts as a master anti-apoptotic regulator by binding to Fas-associated flice-like inhibitory protein (FADD) linking it to caspase 8 , a component of the death-inducing signaling complex (DISC) (171-173). c-FLIP also impacts activation of the mitochondrial mediated pathway by the pro-apoptotic protein BH3 interacting death agonist (BID) (173) and it is an anticancer target which is pursued by many drug discovery programmes (171-173).

miR-708 targets survivin. miR-708 (Figure 5A) expression is attenuated in ccRCC (174). miR-708 induces apoptosis, inhibits migration and invasion, reduces adhesion to ECM and increases the fraction of spindle-shaped cells of A498 and Caki-2 ccRCC cells (174). Intra-tumoral delivery of this miRNA in xenografts of A498 ccRCC cells leads to regression of established tumors in nude mice (174). Survivin was identified as a direct target of miR-708 (174). Its knockdown phenocopies miR-708 re-expression in ccRCC cells (174) and is a predictor of progression and death from ccRCC (175). It is a member of the inhibitor of apoptosis family which modulates the cell cycle, microtubules dynamics and inhibits caspase activation (176). Several survivin inhibitors are under preclinical investigation $(177,178)$.

\section{microRNAs targeting other proteins}

In addition to proteins outlined in the previous sections, other proteins are implicated in oncogenesis and metastasis. They can regulate cell movement, angiogenesis, autophagy, EMT and protein degradation via the proteasome. miRs can modulate their activity.

miR-29b targets MMP2. miR-29c (Figure 5A) inhibits the capacity of ccRCC cells to promote capillary tube formation and to invade ECM gel in vitro (179). LCM6 RCC cells transfected with dexamethasone inducible miR-29b subcutaneously or orthotopically implanted into nude mice give rise to smaller tumors with decreased microvessel density and decreased occurence of intrahepatic metastases, indicating that miR-29 suppresses both angiogenesis and metastasis (179). Matrix metalloproteinase 2 (MMP2) has been identified as a direct target of this miRNA (179). It exerts its anti-angiogenic effect by inhibiting VEGFR2 signaling in endothelial cells (179). It is well documented that degradation and remodelling of the ECM mediates tumor growth and metastasis (180). However, inhibition of MMPs in cancer therapy did not meet the projected clinical endpoints as revealed by numerous clinical trials (181).

\section{miR-204 targets LC3B}

miR-204 (Figure 5A) is a VHL-regulated tumor supressor in ccRCC (182). VHL is lost in the vast majority of ccRCC carcinomas (182). miR-204 containing lentivirus particles inhibit subcutaneously implanted 786-O RCC xenografts after intra-tumoral injection (182). miR-204 expressing 786$\mathrm{O}$ cells do not infiltrate into the kidney parenchyme after implantation into the kidney capsule in contrast to cells expressing an inactive mutant (182). The miRNA is 
A

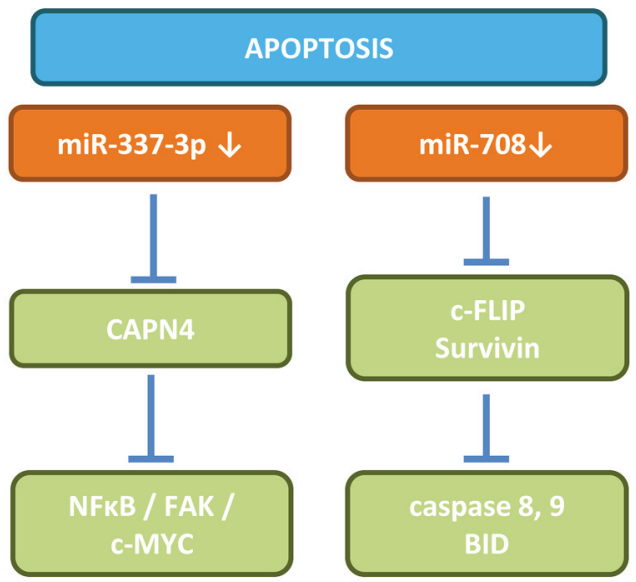

OTHER TARGETS

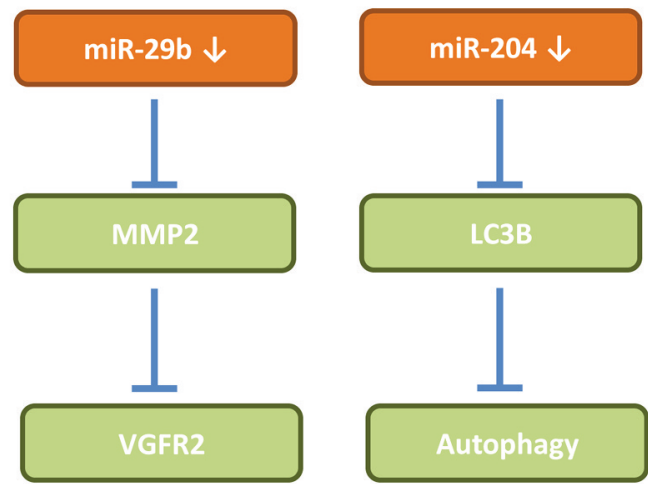

B

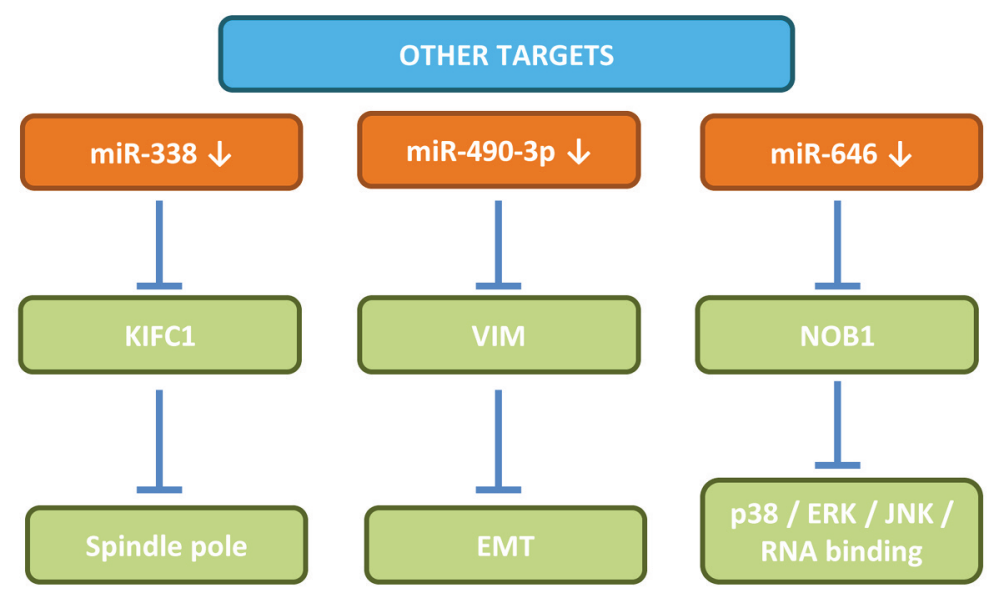

Figure 5. Down-regulated miRs targeting apoptosis-related and other proteins with efficacy in preclinical kidney cancer-related in vivo systems. (A) Apoptosis-related targets. (B) Other exploratory targets. BID: BH3 interacting domain death agonist; CAPN4: calpain small regulatory subunit; FAK: focal adhesion kinase; FLIP: caspase FLICE-like inhibitory protein; LC3B: autophagy protein LC3B; MMP2: matrix metallo-proteinase 2; MYC: transcription factor MYC; NFkB; nuclear factor $k B$; VEGFR2; vascular endothelial growth factor receptor 2; EMT: epithelial mesenchymal transition; ERK: extracellularly-regulated kinase; JNK: c-jun N-terminal kinase; KIF1C: kinesin family member 1; NOB1: nin one binding protein; p38: p38 mitogen-activated protein kinase; VIM: vimentin.

cytotoxic to VHL-, but not to VHL+ RCC cells (182). The autophagy protein LC3B is a direct target of miR-204 and is a mediator of its cytotoxicity (182). LC3B induces macroautophagy which is necessary for ccRCC progression (182). LC3B is also involved in phageosome biogenesis and substrate selection in ccRCC and other types of cancers $(183,184)$. Autophagy plays a context-dependant role in different types of cancers, therefore inhibition or stimulation of this process could be helpful as therapeutic intervention (185). Nevertheless, the role of autophagy in ccRCC remains to be investigated in more detail.

miR-338 targets KIFC1. miR-338 (Figure 5B) inhibits proliferation, migration and invasion of ccRCC in vitro and in vivo by targeting kinesin family member 1 (KIFC1) through the PI3K/AKT signaling pathway (186). KIFC1 is up-regulated in ccRCC and correlates with aggressive clinicopathological parameters (186). It is a member of the kinesin protein family, which are motor proteins that deliver cargo to different cellular destinations by ATP hydrolysis and tubulin binding (187). KIFC1 associates with poor survival in ccRCC, drives tumor malignancy, prevents cancer cell death and is involved in spindle pole organization $(188,189)$. Several kinesin inhibitors are under preclincial and clinical evaluation in diverse types of cancer (190).

miR-490-3p targets vimentin. Orphan testicular receptor T4 (191) induces vimentin (VIM) and inhibits miR-490-3p (Figure 5B) by binding to its promoter (192). VIM was identified as a direct target of miR-490-3p (192). miR-490- 
$3 p$ inhibits tumor growth and metastasis after implantation into the renal capsule of transfected Caki-1 cells in nude mice (192). VIM belongs to the intermediate filament family, is ubiquitously expressed in mesenchymal cells, represents a marker for EMT and correlates with accelerated tumor growth, invasion and prognosis in several types of cancer $(193,194)$.

miR-646 targets NOB1. miR-646 (Figure 5B) is a predictor of distant metastasis in patients with ccRCC (195). In vitro, miR-646 inhibits proliferation and colony formation of 786$\mathrm{O}$ and ACHN ccRCC cell lines (195). In vivo, miR-646 attenuates tumor growth of 786-O and ACHN RCC after subcutaneous implantation into nude mice (196). In these cell lines, miR-646 inhibits formation of key components of the MAPK signaling pathway such as p38, ERK1/2 and cjun N-terminal kinase (JNK) (196). Nin one binding protein (NOB1) was identified as a direct target of miR-646 (196). Down-regulation of NOB1 inhibits activation of the proteasome and stabilizes proteins which increase phosphorylation of key components of the MAPK pathway (196, 197). In addition, NOB1 acts as an RNA binding protein. NOB1 binds to $18 \mathrm{~S}$ ribosomal RNA and is involved in its processing $(198,199)$. NOB1 expression is associated with poor prognosis in several types of cancers (199).

\section{Therapeutic Aspects}

We have identified 10 up-regulated and 33 down-regulated miRs with efficacy in ccRCC-related in preclinical in vivo models. Up-regulated miRs can be inhibited by singlestranded RNAs such as locked nucleic acids (LNA),12-25 nucleotides complementary to the corresponding mRNA (200). An alternative type of $\mathrm{miR}$ inhibitors are $\mathrm{miR}$ sponges which contain multiple miR binding sites that can compete with the corresponding mRNA for binding of the corresponding miR (201). Inhibition of miRs can also be achieved with small molecules which interfere with their transcription or their secondary structure, but specificity issues of the identified compounds are a major issue (200, 201). The corresponding targets are candidates for reconstitution with small molecules or gene therapy. The identified up-regulated miRs are shown in Figure 1. They cover adhesion molecules CADM2 and E-cadherin (miRs146a and -720), tumor supressors such as PTEN and PTENP1 (miR-21), WNT-signaling inhibitors (miR-106-5p), transcription factors such as FOXO3 and enzymes such as DICER (miR-122) and ST3GalIV (miR-193a, -224). Noteworthy, our survey revealed only one hit addressing an epigenetic modifier (miR-144-3p, ARID-1A). This is surprising since several epigenetic modifiers such as BAP1, PBRM1, SET2 and KDM5C play an important role in the pathogenesis of ccRCC (6).
Down-regulated miRs (Figures 2, 3 and 4) are candidates for $\mathrm{miR}$ reconstitution therapy. Their targets are moieties for inhibition by small molecules or mAb-derived entities. Double stranded RNAs functioning as miR-mimetics can be used for restoration of the function of miRs (202). Another option for functional reconstitution of miRs is to express them with appropriate vectors in recipient cells (202).

Among the down-regulated miRs identified, miR-99a (mTOR) and miR-205-5p (VEGF) are directed against targets with drugs approved for treatment of ccRCC as outlined in the previous sections. Several approved drugs for ccRCC target VEGF or vascular endothelial growth factor receptors 1-3 (VEGFR1-3), often jointly (7). Two approved drugs for ccRCC target mTOR (107). Three of the identified down-regulated miRs (miR-30a-3p, -30c-2-3p and -145) target HIF-2 $\alpha$, which after dimerization with HIF-1 $\alpha$, induces transcription of genes involved in the pathogenesis of ccRCC such as VEGF, platelet-derived growth factor B (PDGFR-B), transforming growth factor $\alpha$ (TGF $\alpha$ ), erythropoietin (EPO), SPOP and ECM proteins $(115,116)$. VHL, an E3 ubiquitin ligase, is inactivated in $95 \%$ of sporadic ccRCC with the consequence that its substrates, HIF-2 $\alpha$ and HIF-1 $\alpha$, are not degraded $(115,116)$. PTP 2977 (MK-6482), an orally active and selective HIF-2 $\alpha$ inhibitor showed promising efficacy and tolerability and is presently in Phase III clinical studies in patients with inactivating VHL mutations (203-205).

Our search has identified SPOP (targeted by miR520,372/373) as a tractable target and miR-based agent for treatment of ccRCC. SPOP is induced under hypoxic conditions and functions as an E3 ubiquitin ligase which mediates degradation of PTEN and other tumor suppressors and promotes tumorigenesis by acting as a key regulatory hub in ccRCC $(160,161)$. Another E3 ubiquitin-ligase, CBP (targeted by miR-200a-3p) as a potential therapeutic target, has been revealed by our search. However, more target validation experiments are necessary to substantiate its role as a therapeutic target in ccRCC.

Our survey has identified CDKs and corresponding miRs as targets and therapeutic tools for treatment of ccRCC such as miR-1 (CDK4, CDK6), miR-200c (CDK2) and miR-206c (CDK4, CDK9). CDK4 and CDK6 inhibitors have been approved for treatment of hormone-dependent, HER2negative breast cancer (134). PD-0332991, a potent and selective inhibitor of CDK4 and 6 inhibits proliferation of RCC cells at nanomolar concentrations (206). It remains to be explored whether a therapeutic window exists for CDK inhibitors in patients with ccRCC. Furthermore, RLIP76 (targeted by miR-137) was identified as a druggable transmembrane receptor which induces apoptosis in ccRCC cells both in vitro and in vivo.

In addition to these high priority targets as outlined above, other druggable targets and corresponding miRs have been 
noticed such as CAPN4 (miR-337-3p), c-FLIP/SURVIVIN (miR-708), VHL regulated LC3B (miR-204), kinesin KIF1C (mR-338), AKT2 (miR-148a), PAK5 (miR-106-5p), EphA2 (miR-141) and IGFR1 (miR-193b). However, more target validation experiments are necessary for these targets and their associated miRs to explore their potential for treatment of ccRCC.

Other targets with pending druggability and preliminary target validation have been identified such as: Let-7d (COL3A), miR-28-5p (RAS-1B), miR-32-5p (TR4), miRs143 and -216 (KRAS), miR-200b (LAMA4), miR-490-3p (VIM) and miR-646 (NOB1).

Of note, miR-122 targets DICER (38) and FOXO3 (17) (Figure 1). This may be due to selection of different in vitro and in vivo systems for target identification. The same may be true for miR-780 which targets c-FLIP and Survivin (Figure 3A) $(170,174)$.

miR-based therapy has experienced serious drawbacks in clinical trials due to lack of efficacy or serious adverse reactions (207). Clinical studies evaluating a miR-17 inhibitor in patients with polycystic kidney disease and treatment of patients with hepatitis $\mathrm{C}$ virus infection were put on hold due to toxicity issues (207). A Phase I study of MRX34, a synthetic mimic of miR-34, in patients with multiple types of tumors was shut down due to immunerelated side effects (207). Next generation of miR-related therapeutics with an expected profile of better tolerability and efficacy have been generated (207). Also progress in delivery issues has been achieved (207). COBOMARSEN (MRG-106), an antagonist of miR-155, which is presently evaluated in clinical trials in haematological malignancies is well tolerated and looks promising with respect to efficacy (207). The next couple of years will give us a more realistic estimation of the potential of miRs for the therapy of cancer.

\section{References}

1 American cancer society, cancer facts and figures 2020, Atlanta.Available at: https://www.cancer.org/content/dam/cancerorg/research/cancer-facts-and-statistics/annual-cancer-facts-andfigures/2020/cancer-facts-and-figures-2020.pdf [Last accessed on February 24, 2021]

2 Hsieh JJ, Purdue MP, Signoretti S, Swanton C, Albiges L, Schmidinger M, Heng DY, Larkin J and Ficarra V: Renal cell carcinoma. Nat Rev Dis Primers 3: 17009, 2017. PMID: 28276433. DOI: $10.1038 / \operatorname{nrdp} .2017 .9$

3 Nabi S, Kessler ER, Bernard B, Flaig TW and Lam ET: Renal cell carcinoma: A review of biology and pathophysiology. F1000Res 7: 307, 2018. PMID: 29568504. DOI: 10.12688/f1000research. 13179.1

4 Choueiri TK and Motzer RJ: Systemic therapy for metastatic renal-cell carcinoma. N Engl J Med 376(4): 354-366, 2017. PMID: 28121507. DOI: 10.1056/NEJMra1601333

5 Nickerson ML, Jaeger E, Shi Y, Durocher JA, Mahurkar S, Zaridze D, Matveev V, Janout V, Kollarova H, Bencko V,
Navratilova M, Szeszenia-Dabrowska N, Mates D, Mukeria A, Holcatova I, Schmidt LS, Toro JR, Karami S, Hung R, Gerard GF, Linehan WM, Merino M, Zbar B, Boffetta P, Brennan P, Rothman N, Chow WH, Waldman FM and Moore LE: Improved identification of von Hippel-Lindau gene alterations in clear cell renal tumors. Clin Cancer Res 14(15): 4726-4734, 2008. PMID: 18676741. DOI: 10.1158/1078-0432.CCR-074921

6 Sanchez DJ and Simon MC: Genetic and metabolic hallmarks of clear cell renal cell carcinoma. Biochim Biophys Acta Rev Cancer 1870(1): 23-31, 2018. PMID: 29959988. DOI: 10.1016/j.bbcan. 2018.06.003

7 Sánchez-Gastaldo A, Kempf E, González Del Alba A and Duran I: Systemic treatment of renal cell cancer: A comprehensive review. Cancer Treat Rev 60: 77-89, 2017. PMID: 28898679. DOI: 10.1016/j.ctrv.2017.08.010

$8 \mathrm{Xu} \mathrm{W}$, Atkins MB and McDermott DF: Checkpoint inhibitor immunotherapy in kidney cancer. Nat Rev Urol 17(3): 137-150, 2020. PMID: 32020040. DOI: 10.1038/s41585-020-0282-3

9 Hata A and Kashima R: Dysregulation of microRNA biogenesis machinery in cancer. Crit Rev Biochem Mol Biol 51(3): 121-134, 2016. PMID: 26628006. DOI: 10.3109/10409238.2015.1117054

10 Gulyaeva LF and Kushlinskiy NE: Regulatory mechanisms of microRNA expression. J Transl Med 14(1): 143, 2016. PMID: 27197967. DOI: 10.1186/s12967-016-0893-x

11 Peter ME: Targeting of mRNAs by multiple miRNAs: The next step. Oncogene 29(15): 2161-2164, 2010. PMID: 20190803. DOI: $10.1038 /$ onc.2010.59

12 Hsieh JJ, Purdue MP, Signoretti S, Swanton C, Albiges L, Schmidinger M, Heng DY, Larkin J and Ficarra V: Renal cell carcinoma. Nat Rev Dis Primers 3: 17009, 2017. PMID: 28276433. DOI: $10.1038 /$ nrdp.2017.9

13 Fabbri M: TLRs as miRNA receptors. Cancer Res 72(24): 63336337, 2012. PMID: 23222301. DOI: 10.1158/0008-5472.CAN12-3229

14 Syed SN and Brüne B: MicroRNAs as emerging regulators of signaling in the tumor microenvironment. Cancers (Basel) 12(4): 2020. PMID: 32276464. DOI: 10.3390/cancers 12040911

15 Weidle UH, Dickopf S, Hintermair C, Kollmorgen G, Birzele $\mathrm{F}$ and Brinkmann U: The role of micro RNAs in breast cancer metastasis: Preclinical validation and potential therapeutic targets. Cancer Genomics Proteomics 15(1): 17-39, 2018. PMID: 29275360. DOI: 10.21873/cgp.20062

16 Weidle UH, Birzele F, Kollmorgen G and Nopora A: Potential microRNA-related targets for therapeutic intervention with ovarian cancer metastasis. Cancer Genomics Proteomics 15(1): 1-15, 2018. PMID: 29275359. DOI: 10.21873/cgp.20061

17 Weidle UH, Epp A, Birzele F and Brinkmann U: The functional role of prostate cancer metastasis-related micro-RNAs. Cancer Genomics Proteomics 16(1): 1-19, 2019. PMID: 30587496. DOI: $10.21873 / \operatorname{cgp} .20108$

18 Weidle UH, Birzele F and Nopora A: MicroRNAs as potential targets for therapeutic intervention with metastasis of non-small cell lung cancer. Cancer Genomics Proteomics 16(2): 99-119, 2019. PMID: 30850362 . DOI: $10.21873 / \mathrm{cgp} .20116$

19 Weidle UH, Birzele F and Nopora A: Pancreatic Ductal Adenocarcinoma: MicroRNAs affecting tumor growth and metastasis in preclinical in vivo models. Cancer Genomics Proteomics 16(6): 451-464, 2019. PMID: 31659100. DOI: $10.21873 / \operatorname{cgp} .20149$ 
20 Weidle UH, Schmid D, Birzele F and Brinkmann U: MicroRNAs involved in metastasis of hepatocellular carcinoma: target candidates, functionality and efficacy in animal models and prognostic relevance. Cancer Genomics Proteomics 17(1): 1-21, 2020. PMID: 31882547. DOI: $10.21873 / \mathrm{cgp} .20163$

21 Weidle UH and Nopora A: Identification of microRNAs with in vivo efficacy in multiple myeloma-related xenograft models. Cancer Genomics Proteomics 17(4): 321-334, 2020. PMID: 32576578. DOI: $10.21873 / \mathrm{cgp} .20192$

22 Ali Syeda Z, Langden SSS, Munkhzul C, Lee M and Song SJ: Regulatory mechanism of microRNA expression in cancer. Int $\mathrm{J}$ Mol Sci 21(5): 2020. PMID: 32138313. DOI: 10.3390/ijms 21051723

23 Balatti V and Croce CM: MicroRNA dysregulation and multitargeted therapy for cancer treatment. Adv Biol Regul 75: 100669, 2020. PMID: 31640928. DOI: 10.1016/j.jbior.2019.100669

24 Callegari E, Elamin BK, Giannone F, Milazzo M, Altavilla G, Fornari F, Giacomelli L, D'Abundo L, Ferracin M, Bassi C, Zagatti B, Corrà F, Miotto E, Lupini L, Bolondi L, Gramantieri L, Croce CM, Sabbioni S and Negrini M: Liver tumorigenicity promoted by microRNA-221 in a mouse transgenic model. Hepatology 56(3): 1025-1033, 2012. PMID: 22473819. DOI: 10.1002/hep.25747

25 Yang L, Zhao G, Wang F, Li C and Wang X: Hypoxia-regulated mir-146a targets cell adhesion molecule 2 to promote proliferation, migration, and invasion of clear cell renal cell carcinoma. Cell Physiol Biochem 49(3): 920-931, 2018. PMID: 30184528. DOI: $10.1159 / 000493224$

26 Takai Y, Irie K, Shimizu K, Sakisaka T and Ikeda W: Nectins and nectin-like molecules: Roles in cell adhesion, migration, and polarization. Cancer Sci 94(8): 655-667, 2003. PMID: 12901789. DOI: 10.1111/j.1349-7006.2003.tb01499.x

27 He W, Li X, Xu S, Ai J, Gong Y, Gregg JL, Guan R, Qiu W, Xin D, Gingrich JR, Guo Y and Chang G: Aberrant methylation and loss of CADM2 tumor suppressor expression is associated with human renal cell carcinoma tumor progression. Biochem Biophys Res Commun 435(4): 526-532, 2013. PMID: 23643812. DOI: $10.1016 /$ j.bbrc.2013.04.074

28 Bhat NS, Colden M, Dar AA, Saini S, Arora P, Shahryari V, Yamamura S, Tanaka Y, Kato T, Majid S and Dahiya R: MicroRNA-720 regulates E-cadherin- $\alpha$ E-catenin complex and promotes renal cell carcinoma. Mol Cancer Ther 16(12): 28402848, 2017. PMID: 28802251. DOI: 10.1158/1535-7163.MCT$17-0400$

29 Zhang X, Yang M, Shi H, Hu J, Wang Y, Sun Z and Xu S: Reduced E-cadherin facilitates renal cell carcinoma progression by WNT/ß-catenin signaling activation. Oncotarget $8(12)$ : 1956619576, 2017. PMID: 28223537. DOI: 10.18632/oncotarget.15361

30 Ye M, Fan G, Zhu S, Han W and Xie Y: Low expressions of EHD2 and E-cadherin correlate with a poor prognosis for clear cell renal cell carcinoma. Zhong Nan Da Xue Xue Bao Yi Xue Ban 44(8): 864-870, 2019. PMID: 31570672. DOI: 10.11817/ j.issn.1672-7347.2019.190098

31 Katagiri A, Watanabe R and Tomita Y: E-cadherin expression in renal cell cancer and its significance in metastasis and survival. Br J Cancer 71(2): 376-379, 1995. PMID: 7841055. DOI: $10.1038 / b j c .1995 .76$

32 Yu G, Yao W, Gumireddy K, Li A, Wang J, Xiao W, Chen K, Xiao H, Li H, Tang K, Ye Z, Huang Q and Xu H: Pseudogene PTENP1 functions as a competing endogenous RNA to suppress clear-cell renal cell carcinoma progression. Mol Cancer Ther 13(12): 3086-3097, 2014. PMID: 25249556. DOI: 10.1158/1535-7163.MCT-14-0245

33 Haddadi N, Lin Y, Travis G, Simpson AM, Nassif NT and McGowan EM: PTEN/PTENP1: 'Regulating the regulator of RTK-dependent PI3K/Akt signalling', new targets for cancer therapy. Mol Cancer 17(1): 37, 2018. PMID: 29455665. DOI: 10.1186/s12943-018-0803-3

34 Lee YR, Chen M and Pandolfi PP: The functions and regulation of the PTEN tumour suppressor: New modes and prospects. Nat Rev Mol Cell Biol 19(9): 547-562, 2018. PMID: 29858604. DOI: $10.1038 / \mathrm{s} 41580-018-0015-0$

35 Poliseno L, Haimovic A, Christos PJ, Vega Y Saenz de Miera EC, Shapiro R, Pavlick A, Berman RS, Darvishian F and Osman I: Deletion of PTENP1 pseudogene in human melanoma. J Invest Dermatol 131(12): 2497-2500, 2011. PMID: 21833010. DOI: 10.1038/jid.2011.232

36 Marsit CJ, Zheng S, Aldape K, Hinds PW, Nelson HH, Wiencke JK and Kelsey KT: PTEN expression in non-small-cell lung cancer: Evaluating its relation to tumor characteristics, allelic loss, and epigenetic alteration. Hum Pathol 36(7): 768-776, 2005. PMID: 16084946. DOI: 10.1016/j.humpath.2005.05.006

37 Tang L, Li X, Gao Y, Chen L, Gu L, Chen J, Lyu X, Zhang Y and Zhang X: Phosphatase and tensin homolog (PTEN) expression on oncologic outcome in renal cell carcinoma: A systematic review and meta-analysis. PLoS One 12(7): e0179437, 2017. PMID: 28672019. DOI: 10.1371/journal.pone.0179437

$38 \mathrm{Lu}$ J, Wei JH, Feng ZH, Chen ZH, Wang YQ, Huang Y, Fang Y, Liang YP, Cen JJ, Pan YH, Liao B, Chen WF, Chen W and Luo JH: miR-106b-5p promotes renal cell carcinoma aggressiveness and stem-cell-like phenotype by activating Wnt/ $\beta$-catenin signalling. Oncotarget 8(13): 21461-21471, 2017. PMID: 28423523. DOI: $10.18632 /$ oncotarget.15591

$39 \mathrm{Xu}$ Q, Krause M, Samoylenko A and Vainio S: Wnt Signaling in Renal Cell Carcinoma. Cancers (Basel) 8(6): 2016. PMID: 27322325. DOI: $10.3390 /$ cancers 8060057

40 Majid S, Saini S and Dahiya R: Wnt signaling pathways in urological cancers: Past decades and still growing. Mol Cancer 11: 7, 2012. PMID: 22325146. DOI: 10.1186/1476-4598-11-7

41 Nie W, Ni D, Ma X, Zhang Y, Gao Y, Peng C and Zhang X: miR 122 promotes proliferation and invasion of clear cell renal cell carcinoma by suppressing Forkhead box O3. Int J Oncol 54(2): 559-571, 2019. PMID: 30483771. DOI: 10.3892/ijo.2018.4636

42 Liu Y, Ao X, Ding W, Ponnusamy M, Wu W, Hao X, Yu W, Wang Y, Li P and Wang J: Critical role of FOXO3a in carcinogenesis. Mol Cancer 17(1): 104, 2018. PMID: 30045773. DOI: 10.1186/s12943-018-0856-3

43 Kim CG, Lee H, Gupta N, Ramachandran S, Kaushik I, Srivastava S, Kim SH and Srivastava SK: Role of Forkhead Box Class O proteins in cancer progression and metastasis. Semin Cancer Biol 50: 142-151, 2018. PMID: 28774834. DOI: 10.1016/j.semcancer.2017.07.007

44 Ni D, Ma X, Li HZ, Gao Y, Li XT, Zhang Y, Ai Q, Zhang P, Song EL, Huang QB, Fan Y and Zhang X: Downregulation of FOXO3a promotes tumor metastasis and is associated with metastasis-free survival of patients with clear cell renal cell carcinoma. Clin Cancer Res 20(7): 1779-1790, 2014. PMID: 24486593. DOI: 10.1158/1078-0432.CCR-13-1687

45 Xiao W, Lou N, Ruan H, Bao L, Xiong Z, Yuan C, Tong J, Xu G, Zhou Y, Qu Y, Hu W, Gao Y, Ru Z, Liu L, Xiao H, Chen K, 
Yang H and Zhang X: Mir-144-3p promotes cell proliferation, metastasis, sunitinib resistance in clear cell renal cell carcinoma by downregulating ARID1A. Cell Physiol Biochem 43(6): 2420-2433, 2017. PMID: 29073615. DOI: 10.1159/000484395

46 Yan HB, Wang XF, Zhang Q, Tang ZQ, Jiang YH, Fan HZ, Sun $\mathrm{YH}$, Yang PY and Liu F: Reduced expression of the chromatin remodeling gene ARID1A enhances gastric cancer cell migration and invasion via downregulation of E-cadherin transcription. Carcinogenesis 35(4): 867-876, 2014. PMID: 24293408. DOI: $10.1093 /$ carcin/bgt398

47 Guan B, Wang TL and Shih IeM: ARID1A, a factor that promotes formation of SWI/SNF-mediated chromatin remodeling, is a tumor suppressor in gynecologic cancers. Cancer Res 71(21): 6718-6727, 2011. PMID: 21900401. DOI: 10.1158/0008-5472.CAN-11-1562

48 Somsuan K, Peerapen P, Boonmark W, Plumworasawat S, Samol R, Sakulsak N and Thongboonkerd V: ARID1A knockdown triggers epithelial-mesenchymal transition and carcinogenesis features of renal cells: Role in renal cell carcinoma. FASEB J 33(11): 12226-12239, 2019. PMID: 31424966. DOI: 10.1096/fj.201802720RR

49 Park JH, Lee C, Suh JH, Chae JY, Kim HW and Moon KC: Decreased ARID1A expression correlates with poor prognosis of clear cell renal cell carcinoma. Hum Pathol 46(3): 454-460, 2015. PMID: 25628030. DOI: 10.1016/j.humpath.2014.12.002

50 Pal SK, Sonpavde G, Agarwal N, Vogelzang NJ, Srinivas S, Haas NB, Signoretti S, McGregor BA, Jones J, Lanman RB, Banks KC and Choueiri TK: Evolution of circulating tumor dna profile from first-line to subsequent therapy in metastatic renal cell carcinoma. Eur Urol 72(4): 557-564, 2017. PMID: 28413127. DOI: 10.1016/j.eururo.2017.03.046

51 Jiang W, Dulaimi E, Devarajan K, Parsons T, Wang Q, O'Neill R, Solomides C, Peiper SC, Testa JR, Uzzo R and Yang H: Intratumoral heterogeneity analysis reveals hidden associations between protein expression losses and patient survival in clear cell renal cell carcinoma. Oncotarget 8(23): 37423-37434, 2017. PMID: 28445125. DOI: 10.18632/oncotarget.16965

52 Jiang T, Chen X, Su C, Ren S and Zhou C: Pan-cancer analysis of ARIDIA alterations as biomarkers for immunotherapy outcomes. J Cancer 11(4): 776-780, 2020. PMID: 31949479. DOI: $10.7150 /$ jca.41296

53 Pan Y, Hu J, Ma J, Qi X, Zhou H, Miao X, Zheng W and Jia L: MiR-193a-3p and miR-224 mediate renal cell carcinoma progression by targeting alpha-2,3-sialyltransferase IV and the phosphatidylinositol 3 kinase/Akt pathway. Mol Carcinog 57(8): 1067-1077, 2018. PMID: 29667779. DOI: 10.1002 mc. 22826

54 Fu C, Zhao H, Wang Y, Cai H, Xiao Y, Zeng Y and Chen H: Tumor-associated antigens: Tn antigen, sTn antigen, and T antigen. HLA 88(6): 275-286, 2016. PMID: 27679419. DOI: $10.1111 / \tan .12900$

$55 \mathrm{Li} \mathrm{F}$ and Ding J: Sialylation is involved in cell fate decision during development, reprogramming and cancer progression. Protein Cell 10(8): 550-565, 2019. PMID: 30478534. DOI: 10.1007/s 13238-018-0597-5

56 Zhang Z, Wuhrer M and Holst S: Serum sialylation changes in cancer. Glycoconj J 35(2): 139-160, 2018. PMID: 29680984. DOI: $10.1007 / \mathrm{s} 10719-018-9820-0$

57 Sasaki K, Watanabe E, Kawashima K, Sekine S, Dohi T, Oshima M, Hanai N, Nishi T and Hasegawa M: Expression cloning of a novel Gal beta (1-3/1-4) GlcNAc alpha 2,3sialyltransferase using lectin resistance selection. J Biol Chem 268(30): 22782-22787, 1993. PMID: 7901202.

58 Chang ML, Eddy RL, Shows TB and Lau JT: Three genes that encode human beta-galactoside alpha 2,3-sialyltransferases. Structural analysis and chromosomal mapping studies. Glycobiology 5(3): 319-325, 1995. PMID: 7655169. DOI: 10.1093/glycob/5.3.319

59 Fan Y, Ma X, Li H, Gao Y, Huang Q, Zhang Y, Bao X, Du Q, Luo G, Liu K, Meng Q, Zhao C and Zhang X: MiR-122 promotes metastasis of clear-cell renal cell carcinoma by downregulating Dicer. Int J Cancer 142(3): 547-560, 2018. PMID: 28921581. DOI: 10.1002/ijc. 31050

60 Song MS and Rossi JJ: Molecular mechanisms of Dicer: Endonuclease and enzymatic activity. Biochem J 474(10): 16031618, 2017. PMID: 28473628. DOI: 10.1042/BCJ20160759

61 Ma X, Fan Y, Gao Y, Zhang Y, Huang Q, Ai Q, Ni D, Chen W, Zhang P, Song E, Wang B, Shi T, Zheng T and Zhang X: Dicer is down-regulated in clear cell renal cell carcinoma and in vitro Dicer knockdown enhances malignant phenotype transformation. Urol Oncol 32(1): 46.e9-46.17, 2014. PMID: 24094887. DOI: 10.1016/j.urolonc.2013.06.011

62 Fan Y, Li H, Ma X, Gao Y, Bao X, Du Q, Ma M, Liu K, Yao Y, Huang $\mathrm{Q}$, Zhang $\mathrm{Y}$ and Zhang $\mathrm{X}$ : Dicer suppresses the malignant phenotype in VHL-deficient clear cell renal cell carcinoma by inhibiting HIF-2 $\alpha$. Oncotarget 7(14): 18280-18294, 2016. PMID: 26943772. DOI: 10.18632/oncotarget.7807

63 Wang M, Gao H, Qu H, Li J, Liu K and Han Z: MiR-137 suppresses tumor growth and metastasis in clear cell renal cell carcinoma. Pharmacol Rep 70(5): 963-971, 2018. PMID: 30107346. DOI: 10.1016/j.pharep.2018.04.006

64 Awasthi S, Singhal SS, Awasthi YC, Martin B, Woo JH, Cunningham CC and Frankel AE: RLIP76 and cancer. Clin Cancer Res 14(14): 4372-4377, 2008. PMID: 18628450. DOI: 10.1158/1078-0432.CCR-08-0145

65 Singhal SS, Singhal J, Yadav S, Sahu M, Awasthi YC and Awasthi S: RLIP76: A target for kidney cancer therapy. Cancer Res 69(10): 4244-4251, 2009. PMID: 19417134. DOI: 10.1158/0008-5472.CAN-08-3521

66 Singhal SS, Singhal J, Figarola J, Horne D and Awasthi S: RLIP76 Targeted Therapy for Kidney Cancer. Pharm Res 32(10): 3123-3136, 2015. PMID: 26021465. DOI: 10.1007/ s11095-015-1723-1

67 Vatsyayan R, Lelsani PC, Awasthi S and Singhal SS: RLIP76: A versatile transporter and an emerging target for cancer therapy. Biochem Pharmacol 79(12): 1699-1705, 2010. PMID: 20097178. DOI: 10.1016/j.bcp.2010.01.016

68 Chen X, Wang X, Ruan A, Han W, Zhao Y, Lu X, Xiao P, Shi $\mathrm{H}$, Wang R, Chen L, Chen S, Du Q, Yang H and Zhang X: MiR-141 is a key regulator of renal cell carcinoma proliferation and metastasis by controlling EphA2 expression. Clin Cancer Res 20(10): 2617-2630, 2014. PMID: 24647573. DOI: 10.1158/ 1078-0432.CCR-13-3224

69 Talaat IM, Okap IS, Abou Youssif TM, Hachim IY, Hachim MY and Sheikh SME: The prognostic value of ephrin type-A2 receptor and Ki-67 in renal cell carcinoma patients: An immunohistochemical and bioinformatical approach; A STROBE - compliant article. Medicine (Baltimore) 99(19): e20191, 2020. PMID: 32384514. DOI: 10.1097/MD.0000000 000020191 
70 Buckens OJ, El Hassouni B, Giovannetti E and Peters GJ: The role of Eph receptors in cancer and how to target them: Novel approaches in cancer treatment. Expert Opin Investig Drugs 29(6): 567-582, 2020. PMID: 32348169. DOI: 10.1080/ 13543784.2020 .1762566

71 Tandon M, Vemula SV and Mittal SK: Emerging strategies for EphA2 receptor targeting for cancer therapeutics. Expert Opin Ther Targets 15(1): 31-51, 2011. PMID: 21142802. DOI: $10.1517 / 14728222.2011 .538682$

72 Ireton $\mathrm{RC}$ and Chen $\mathrm{J}$ : EphA2 receptor tyrosine kinase as a promising target for cancer therapeutics. Curr Cancer Drug Targets 5(3): 149-157, 2005. PMID: 15892616. DOI: $10.2174 / 1568009053765780$

73 Xu X, Wu J, Li S, Hu Z, Xu X, Zhu Y, Liang Z, Wang X, Lin Y, Mao Y, Chen H, Luo J, Liu B, Zheng X and Xie L: Downregulation of microRNA-182-5p contributes to renal cell carcinoma proliferation via activating the AKT/FOXO3a signaling pathway. Mol Cancer 13: 109, 2014. PMID: 24886554. DOI: $10.1186 / 1476-4598-13-109$

74 Bickel PE, Scherer PE, Schnitzer JE, Oh P, Lisanti MP and Lodish HF: Flotillin and epidermal surface antigen define a new family of caveolae-associated integral membrane proteins. J Biol Chem 272(21): 13793-13802, 1997. PMID: 9153235. DOI: $10.1074 / j b c .272 .21 .13793$

75 Volonte D, Galbiati F, Li S, Nishiyama K, Okamoto T and Lisanti MP: Flotillins/cavatellins are differentially expressed in cells and tissues and form a hetero-oligomeric complex with caveolins in vivo. Characterization and epitope-mapping of a novel flotillin-1 monoclonal antibody probe. J Biol Chem 274(18): 12702-12709, 1999. PMID: 10212252. DOI: $10.1074 / \mathrm{jbc} .274 .18 .12702$

76 Guo AY, Liang XJ, Liu RJ, Li XX, Bi W, Zhou LY, Tang CE, Yan A, Chen ZC and Zhang PF: Flotilin-1 promotes the tumorigenicity and progression of malignant phenotype in human lung adenocarcinoma. Cancer Biol Ther 18(9): 715-722, 2017. PMID: 28825855. DOI: 10.1080/15384047.2017.1360445

77 Chen J, Deng T, Li X and Cai W: MiR-193b inhibits the growth and metastasis of renal cell carcinoma by targeting IGF1R. Artif Cells Nanomed Biotechnol 47(1): 2058-2064, 2019. PMID: 31126198. DOI: 10.1080/21691401.2019.1620251

78 Yuen JS, Akkaya E, Wang Y, Takiguchi M, Peak S, Sullivan M, Protheroe AS and Macaulay VM: Validation of the type 1 insulin-like growth factor receptor as a therapeutic target in renal cancer. Mol Cancer Ther 8(6): 1448-1459, 2009. PMID: 19509240. DOI: 10.1158/1535-7163.MCT-09-0101

79 Tracz AF, Szczylik C, Porta C and Czarnecka AM: Insulin-like growth factor-1 signaling in renal cell carcinoma. BMC Cancer 16: 453, 2016. PMID: 27405474. DOI: 10.1186/s12885-016-2437-4

80 Werner H, Sarfstein R and Bruchim I: Investigational IGF1R inhibitors in early stage clinical trials for cancer therapy. Expert Opin Investig Drugs 28(12): 1101-1112, 2019. PMID: 31731883. DOI: $10.1080 / 13543784.2019 .1694660$

81 Wang C, Wu C, Yang Q, Ding M, Zhong J, Zhang CY, Ge J, Wang $\mathrm{J}$ and Zhang C: MiR-28-5p acts as a tumor suppressor in renal cell carcinoma for multiple antitumor effects by targeting RAP1B. Oncotarget 7(45): 73888-73902, 2016. PMID: 27729617. DOI: 10.18632 /oncotarget.12516

82 Stefanini L and Bergmeier W: RAP GTPases and platelet integrin signaling. Platelets 30(1): 41-47, 2019. PMID: 29863951. DOI: 10.1080/09537104.2018.1476681
83 Zhang L, Cui M, Song L, Zhang M and Zhang J: Function, significance, and regulation of rap1b in malignancy. Crit Rev Eukaryot Gene Expr 29(2): 151-160, 2019. PMID: 31679270. DOI: $10.1615 /$ CritRevEukaryotGeneExpr.2019025997

84 Chrzanowska-Wodnicka M, Kraus AE, Gale D, White GC 2nd and Vansluys J: Defective angiogenesis, endothelial migration, proliferation, and MAPK signaling in Rap1b-deficient mice. Blood 111(5): 2647-2656, 2008. PMID: 17993608. DOI: 10.1182/blood-2007-08-109710

85 Cui L, Zhou H, Zhao H, Zhou Y, Xu R, Xu X, Zheng L, Xue Z, Xia W, Zhang B, Ding T, Cao Y, Tian Z, Shi Q and He X: MicroRNA-99a induces G1-phase cell cycle arrest and suppresses tumorigenicity in renal cell carcinoma. BMC Cancer 12: 546, 2012. PMID: 23173671. DOI: $10.1186 / 1471-2407-12-546$

86 Petroulakis E, Mamane Y, Le Bacquer O, Shahbazian D and Sonenberg N: mTOR signaling: implications for cancer and anticancer therapy. Br J Cancer 96(Suppl): R11-R15, 2007. PMID: 17393579

87 Vignot S, Faivre S, Aguirre D and Raymond E: mTOR-targeted therapy of cancer with rapamycin derivatives. Ann Oncol 16(4): 525-537, 2005. PMID: 15728109. DOI: 10.1093/annonc/ mdi113

88 Kapoor A: Inhibition of mTOR in kidney cancer. Curr Oncol 16(Suppl 1): S33-S39, 2009. PMID: 19478899. DOI: 10.3747/ co.v16i0.419

89 Ghosh AP and Sudarshan S: Genetics of renal cancer: Focus on MTOR. Aging (Albany NY) 8(3): 421-422, 2016. PMID: 27017990. DOI: 10.18632 aging.100937

$90 \mathrm{Xu} \mathrm{J}$, Pham CG, Albanese SK, Dong Y, Oyama T, Lee CH, Rodrik-Outmezguine V, Yao Z, Han S, Chen D, Parton DL, Chodera JD, Rosen N, Cheng EH and Hsieh JJ: Mechanistically distinct cancer-associated mTOR activation clusters predict sensitivity to rapamycin. J Clin Invest 126(9): 3526-3540, 2016. PMID: 27482884. DOI: 10.1172/JCI86120

91 Pan YJ, Wei LL, Wu XJ, Huo FC, Mou J and Pei DS: MiR106a-5p inhibits the cell migration and invasion of renal cell carcinoma through targeting PAK5. Cell Death Dis 8(10): e3155, 2017. PMID: 29072688. DOI: 10.1038/cddis.2017.561

92 Ye DZ and Field J: PAK signaling in cancer. Cell Logist 2(2): 105-116, 2012. PMID: 23162742. DOI: $10.4161 / \mathrm{cl} .21882$

93 Li YK, Zou J, Ye DM, Zeng Y, Chen CY, Luo GF and Zeng X: Human p21-activated kinase 5 (PAK5) expression and potential mechanisms in relevant cancers: Basic and clinical perspectives for molecular cancer therapeutics. Life Sci 241: 117113, 2020. PMID: 31805288. DOI: 10.1016/j.lfs.2019.117113

94 Takai T, Tsujino T, Yoshikawa Y, Inamoto T, Sugito N, Kuranaga Y, Heishima K, Soga T, Hayashi K, Miyata K, Kataoka K, Azuma H and Akao Y: Synthetic miR-143 exhibited an anticancer effect via the downregulation of K-RAS networks of renal cell cancer cells in vitro and in vivo. Mol Ther 27(5): 1017-1027, 2019. PMID: 30930112. DOI: 10.1016/j.ymthe.2019.03.004

95 Wang Y, Dong D, Jiang S, Zhang E, Zheng W, Mao L, Li W, Zhou J, Fan L, Cheng R, Li Z, Fang Z, Gui Y and Li X: miR$216 \mathrm{~b}$ post-transcriptionally downregulates oncogene KRAS and inhibits cell proliferation and invasion in clear cell renal cell carcinoma. Cell Physiol Biochem 49(5): 1755-1765, 2018. PMID: 30231239. DOI: 10.1159/000493621

96 McCormick F: K-Ras protein as a drug target. J Mol Med (Berl) 94(3): 253-258, 2016. PMID: 26960760. DOI: $10.1007 / \mathrm{s} 00109-016-1382-7$ 
97 Keeton AB, Salter EA and Piazza GA: The RAS-effector interaction as a drug target. Cancer Res 77(2): 221-226, 2017. PMID: 28062402. DOI: 10.1158/0008-5472.CAN-16-0938

98 Yang W, Zheng Y, Xia Y, Ji H, Chen X, Guo F, Lyssiotis CA, Aldape K, Cantley LC and Lu Z: ERK1/2-dependent phosphorylation and nuclear translocation of PKM2 promotes the Warburg effect. Nat Cell Biol 14(12): 1295-1304, 2012. PMID: 23178880. DOI: $10.1038 /$ ncb2629

99 McCormick F: KRAS as a therapeutic target. Clin Cancer Res 21(8): 1797-1801, 2015. PMID: 25878360. DOI: 10.1158/10780432.CCR-14-2662

100 Lu S, Jang H, Gu S, Zhang J and Nussinov R: Drugging ras GTPase: A comprehensive mechanistic and signaling structural view. Chem Soc Rev 45(18): 4929-4952, 2016. PMID: 27396271. DOI: $10.1039 / \mathrm{c} 5 \mathrm{cs} 00911 \mathrm{a}$

101 Mai TT and Lito P: A treatment strategy for KRAS-driven tumors. Nat Med 24(7): 902-904, 2018. PMID: 29988139. DOI: 10.1038/s41591-018-0111-x

102 Kumar A, Kumari N, Gupta V and Prasad R: Renal Cell Carcinoma: Molecular aspects. Indian J Clin Biochem 33(3): 246254, 2018. PMID: 30072823. DOI: 10.1007/s12291-017-0713-y

103 Cao H, Liu Z, Wang R, Zhang X, Yi W, Nie G, Yu Y, Wang G and Zhu M: MiR-148a suppresses human renal cell carcinoma malignancy by targeting AKT2. Oncol Rep 37(1): 147-154, 2017. PMID: 27878305. DOI: 10.3892/or.2016.5257

104 Wang Q, Chen X and Hay N: Akt as a target for cancer therapy: More is not always better (lessons from studies in mice). Br J Cancer 117(2): 159-163, 2017. PMID: 28557977. DOI: 10.1038/ bjc. 2017.153

105 Roy NK, Bordoloi D, Monisha J, Padmavathi G, Kotoky J, Golla R and Kunnumakkara AB: Specific targeting of Akt kinase isoforms: Taking the precise path for prevention and treatment of cancer. Curr Drug Targets 18(4): 421-435, 2017. PMID: 26953242. DOI: 10.2174/1389450117666160307145236

106 Toschi A, Lee E, Gadir N, Ohh M and Foster DA: Differential dependence of hypoxia-inducible factors 1 alpha and 2 alpha on mTORC1 and mTORC2. J Biol Chem 283(50): 3449534499, 2008. PMID: 18945681. DOI: 10.1074/jbc.C800170200

107 Iida M, Harari PM, Wheeler DL and Toulany M: Targeting AKT/PKB to improve treatment outcomes for solid tumors. Mutat Res 819-820: 111690, 2020. PMID: 32120136. DOI: 10.1016/j.mrfmmm.2020.111690

108 Huang J, Wang X, Wen G and Ren Y: miRNA 205 5p functions as a tumor suppressor by negatively regulating VEGFA and $\mathrm{PI} 3 \mathrm{~K} / \mathrm{Akt} / \mathrm{mTOR}$ signaling in renal carcinoma cells. Oncol Rep 42(5): 1677-1688, 2019. PMID: 31545453. DOI: 10.3892/or.2019. 7307

109 Mantia CM and McDermott DF: Vascular endothelial growth factor and programmed death-1 pathway inhibitors in renal cell carcinoma. Cancer 125(23): 4148-4157, 2019. PMID: 31532565. DOI: $10.1002 /$ cncr.32361

110 Hsieh JJ, Purdue MP, Signoretti S, Swanton C, Albiges L, Schmidinger M, Heng DY, Larkin J and Ficarra V: Renal cell carcinoma. Nat Rev Dis Primers 3: 17009, 2017. PMID: 28276433. DOI: $10.1038 /$ nrdp.2017.9

111 Salgia NJ, Dara Y, Bergerot P, Salgia M and Pal SK: The changing landscape of management of metastatic renal cell carcinoma: Current treatment options and future directions. Curr Treat Options Oncol 20(5): 41, 2019. PMID: 30937639. DOI: $10.1007 / \mathrm{s} 11864-019-0638-1$
112 Mathew LK, Lee SS, Skuli N, Rao S, Keith B, Nathanson KL, Lal P and Simon MC: Restricted expression of miR-30c-2-3p and miR-30a-3p in clear cell renal cell carcinomas enhances HIF2 $\alpha$ activity. Cancer Discov 4(1): 53-60, 2014. PMID: 24189146. DOI: 10.1158/2159-8290.CD-13-0291

$113 \mathrm{Kim}$ W and Kaelin WG Jr: The von Hippel-Lindau tumor suppressor protein: New insights into oxygen sensing and cancer. Curr Opin Genet Dev 13(1): 55-60, 2003. PMID: 12573436. DOI: $10.1016 / \mathrm{s} 0959-437 \times(02) 00010-2$

114 Nakazawa MS, Keith B and Simon MC: Oxygen availability and metabolic adaptations. Nat Rev Cancer 16(10): 663-673, 2016. PMID: 27658636. DOI: 10.1038/nrc.2016.84

115 Raval RR, Lau KW, Tran MG, Sowter HM, Mandriota SJ, Li JL, Pugh CW, Maxwell PH, Harris AL and Ratcliffe PJ: Contrasting properties of hypoxia-inducible factor 1 (HIF-1) and HIF-2 in von Hippel-Lindau-associated renal cell carcinoma. Mol Cell Biol 25(13): 5675-5686, 2005. PMID: 15964822. DOI: 10.1128/MCB.25.13.5675-5686.2005

116 Kondo K, Kim WY, Lechpammer M and Kaelin WG Jr: Inhibition of HIF2alpha is sufficient to suppress pVHLdefective tumor growth. PLoS Biol 1(3): E83, 2003. PMID: 14691554. DOI: 10.1371/journal.pbio.0000083

117 Chen Y, Sun Y, Rao Q, Xu H, Li L and Chang C: Androgen receptor (AR) suppresses miRNA-145 to promote renal cell carcinoma (RCC) progression independent of VHL status. Oncotarget 6(31): 31203-31215, 2015. PMID: 26304926. DOI: 10.18632 /oncotarget. 4522

118 Shinder BM, Shupe A, Lee GT, Stein MN, Kim IY and Singer EA: Role of the androgen signaling axis in genitourinary malignancies. Transl Cancer Res 7(4): 1135-1142, 2018. PMID: 30701159. DOI: $10.21037 /$ tcr.2018.03.41

119 Lee GT, Han CS, Kwon YS, Patel R, Modi PK, Kwon SJ, Faiena I, Patel N, Singer EA, Ahn HJ, Kim WJ and Kim IY: Intracrine androgen biosynthesis in renal cell carcinoma. Br J Cancer 116(7): 937-943, 2017. PMID: 28253524. DOI: 10.1038/bjc.2017.42

120 Huang Q, Sun Y, Ma X, Gao Y, Li X, Niu Y, Zhang X and Chang $C$ : Androgen receptor increases hematogenous metastasis yet decreases lymphatic metastasis of renal cell carcinoma. Nat Commun 8(1): 918, 2017. PMID: 29030639. DOI: 10.1038/s41467-017-00701-6

121 Wang M, Sun Y, Xu J, Lu J, Wang K, Yang DR, Yang G, Li G and Chang C: Preclinical studies using miR-32-5p to suppress clear cell renal cell carcinoma metastasis via altering the miR32-5p/TR4/HGF/Met signaling. Int J Cancer 143(1): 100-112, 2018. PMID: 29396852. DOI: 10.1002/ijc.31289

122 Chang C, Da Silva SL, Ideta R, Lee Y, Yeh S and Burbach JP: Human and rat TR4 orphan receptors specify a subclass of the steroid receptor superfamily. Proc Natl Acad Sci USA 91(13): 6040-6044, 1994. PMID: 8016112. DOI: 10.1073/pnas.91.13.6040

123 Lin SJ, Yang DR, Yang G, Lin CY, Chang HC, Li G and Chang C: TR2 and TR4 orphan nuclear receptors: An overview. Curr Top Dev Biol 125: 357-373, 2017. PMID: 28527578. DOI: 10.1016/bs.ctdb.2017.02.002

124 Nandagopal L, Sonpavde GP and Agarwal N: Investigational MET inhibitors to treat renal cell carcinoma. Expert Opin Investig Drugs 28(10): 851-860, 2019. PMID: 31554440. DOI: 10.1080/13543784.2019.1673366

125 Wang K, Jin W, Jin P, Fei X, Wang X and Chen X: MiR-211$5 \mathrm{p}$ suppresses metastatic behavior by targeting SNAI1 in renal 
cancer. Mol Cancer Res 15(4): 448-456, 2017. PMID: 28057716. DOI: 10.1158/1541-7786.MCR-16-0288

126 Haraguchi M, Sato M and Ozawa M: CRISPR/Cas9n-mediated deletion of the snail 1Gene (SNAI1) reveals its role in regulating cell morphology, cell-cell interactions, and gene expression in ovarian cancer (RMG-1) Cells. PLoS One 10(7): e0132260, 2015. PMID: 26161782. DOI: 10.1371/journal.pone. 0132260

127 G, Del Sol A and Friederich E: A novel network integrating a miRNA-203/SNAI1 feedback loop which regulates epithelial to mesenchymal transition. PLoS One 7(4): e35440, 2012. PMID: 22514743. DOI: 10.1371/journal.pone.0035440

$128 \mathrm{Xu} \mathrm{H}, \mathrm{Xu}$ WH, Ren F, Wang J, Wang HK, Cao DL, Shi GH, Qu YY, Zhang HL and Ye DW: Prognostic value of epithelialmesenchymal transition markers in clear cell renal cell carcinoma. Aging (Albany NY) 12(1): 866-883, 2020. PMID: 31915310. DOI: 10.18632/aging. 102660

129 Carleton M, Cleary MA and Linsley PS: MicroRNAs and cell cycle regulation. Cell Cycle 6(17): 2127-2132, 2007. PMID: 17786041. DOI: 10.4161/cc.6.17.4641

$130 \mathrm{Hu} \mathrm{H}$ and Gatti RA: MicroRNAs: New players in the DNA damage response. J Mol Cell Biol 3(3): 151-158, 2011. PMID: 21183529. DOI: $10.1093 / \mathrm{jmcb} / \mathrm{mjq042}$

131 Zhang X, Xiao D, Wang Z, Zou Y, Huang L, Lin W, Deng Q, Pan H, Zhou J, Liang C and He J: MicroRNA-26a/b regulate DNA replication licensing, tumorigenesis, and prognosis by targeting CDC6 in lung cancer. Mol Cancer Res 12(11): 15351546, 2014. PMID: 25100863. DOI: 10.1158/1541-7786.MCR13-0641

132 Champeris Tsaniras S, Delinasios GJ, Petropoulos M, Panagopoulos A, Anagnostopoulos AK, Villiou M, Vlachakis D, Bravou V, Stathopoulos GT and Taraviras S: DNA replication inhibitor geminin and retinoic acid signaling participate in complex interactions associated with pluripotency. Cancer Genomics Proteomics 16(6): 593-601, 2019. PMID: 31659113. DOI: $10.21873 / \mathrm{cgp} .20162$

133 Xiao H, Zeng J, Li H, Chen K, Yu G, Hu J, Tang K, Zhou H, Huang Q, Li A, Li Y, Ye Z, Wang J and Xu H: MiR-1 downregulation correlates with poor survival in clear cell renal cell carcinoma where it interferes with cell cycle regulation and metastasis. Oncotarget 6(15): 13201-13215, 2015. PMID: 26036633. DOI: $10.18632 /$ oncotarget. 3915

134 Choo JR and Lee SC: CDK4-6 inhibitors in breast cancer: Current status and future development. Expert Opin Drug Metab Toxicol 14(11): 1123-1138, 2018. PMID: 30360668. DOI: $10.1080 / 17425255.2018 .1541347$

135 Wang B, David MD and Schrader JW: Absence of caprin-1 results in defects in cellular proliferation. J Immunol 175(7): 4274-4282, 2005. PMID: 16177067. DOI: 10.4049/jimmunol.175.7.4274

136 Zhou W, Gross KM and Kuperwasser C: Molecular regulation of Snai2 in development and disease. J Cell Sci 132(23): 2019. PMID: 31792043. DOI: 10.1242/jcs.235127

137 Cobaleda C, Pérez-Caro M, Vicente-Dueñas C and Sánchez-García I: Function of the zinc-finger transcription factor SNAI2 in cancer and development. Annu Rev Genet 41: 41-61, 2007. PMID: 17550342. DOI: 10.1146/annurev.genet.41.110306.130146

138 Wang X, Chen X, Han W, Ruan A, Chen L, Wang R, Xu Z, Xiao P, Lu X, Zhao Y, Zhou J, Chen S, Du Q, Yang H and Zhang X: MiR-200c targets CDK2 and suppresses tumorigenesis in renal cell carcinoma. Mol Cancer Res 13(12): 1567-1577, 2015. PMID: 26248649. DOI: 10.1158/1541-7786.MCR-15-0128
139 Tadesse S, Anshabo AT, Portman N, Lim E, Tilley W, Caldon CE and Wang S: Targeting CDK2 in cancer: challenges and opportunities for therapy. Drug Discov Today 25(2): 406-413, 2020. PMID: 31839441. DOI: 10.1016/j.drudis.2019.12.001

140 Tadesse S, Caldon EC, Tilley W and Wang S: Cyclin-dependent kinase 2 inhibitors in cancer therapy: An update. J Med Chem 62(9): 4233-4251, 2019. PMID: 30543440. DOI: 10.1021/ acs.jmedchem. $8 \mathrm{~b} 01469$

141 Hongo F, Takaha N, Oishi M, Ueda T, Nakamura T, Naitoh Y, Naya Y, Kamoi K, Okihara K, Matsushima T, Nakayama S, Ishihara H, Sakai T and Miki T: CDK1 and CDK2 activity is a strong predictor of renal cell carcinoma recurrence. Urol Oncol 32(8): 1240-1246, 2014. PMID: 25443276. DOI: 10.1016/j.urolonc.2014.05.006

142 Xiao H, Xiao W, Cao J, Li H, Guan W, Guo X, Chen K, Zheng $\mathrm{T}$, Ye Z, Wang $\mathrm{J}$ and $\mathrm{Xu} \mathrm{H}$ : miR-206 functions as a novel cell cycle regulator and tumor suppressor in clear-cell renal cell carcinoma. Cancer Lett 374(1): 107-116, 2016. PMID: 26808577. DOI: 10.1016/j.canlet.2016.01.032

143 O'Leary B, Finn RS and Turner NC: Treating cancer with selective CDK4/6 inhibitors. Nat Rev Clin Oncol 13(7): 417430, 2016. PMID: 27030077. DOI: 10.1038/nrclinonc.2016.26

144 Morales F and Giordano A: Overview of CDK9 as a target in cancer research. Cell Cycle 15(4): 519-527, 2016. PMID: 26766294. DOI: 10.1080/15384101.2016.1138186

145 John RR, Malathi N, Ravindran C and Anandan S: Mini review: Multifaceted role played by cyclin D1 in tumor behavior. Indian J Dent Res 28(2): 187-192, 2017. PMID: 28611330. DOI: 10.4103/ijdr.IJDR_697_16

146 Qie S and Diehl JA: Cyclin D1, cancer progression, and opportunities in cancer treatment. J Mol Med (Berl) 94(12): 13131326, 2016. PMID: 27695879. DOI: 10.1007/s00109-016-1475-3

147 Li Y, Guan B, Liu J, Zhang Z, He S, Zhan Y, Su B, Han H, Zhang X, Wang B, Li X, Zhou L and Zhao W: MicroRNA-200b is downregulated and suppresses metastasis by targeting LAMA4 in renal cell carcinoma. EBioMedicine 44: 439-451, 2019. PMID: 31130475. DOI: 10.1016/j.ebiom.2019.05.041

148 Vainionpää N, Lehto VP, Tryggvason K and Virtanen I: Alpha4 chain laminins are widely expressed in renal cell carcinomas and have a de-adhesive function. Lab Invest 87(8): 780-791, 2007. PMID: 17533363. DOI: $10.1038 /$ labinvest. 3700592

149 Yousif LF, Di Russo J and Sorokin L: Laminin isoforms in endothelial and perivascular basement membranes. Cell Adh Migr 7(1): 101-110, 2013. PMID: 23263631. DOI: $10.4161 / \mathrm{cam} .22680$

150 Wragg JW, Finnity JP, Anderson JA, Ferguson HJ, Porfiri E, Bhatt RI, Murray PG, Heath VL and Bicknell R: MCAM and LAMA4 are highly enriched in tumor blood vessels of renal cell carcinoma and predict patient outcome. Cancer Res 76(8): 2314-2326, 2016. PMID: 26921326. DOI: 10.1158/00085472.CAN-15-1364

151 Su B, Zhao W, Shi B, Zhang Z, Yu X, Xie F, Guo Z, Zhang X, Liu J, Shen Q, Wang J, Li X, Zhang Z and Zhou L: Let-7d suppresses growth, metastasis, and tumor macrophage infiltration in renal cell carcinoma by targeting COL3A1 and CCL7. Mol Cancer 13: 206, 2014. PMID: 25193015. DOI: 10.1186/1476-4598-13-206

152 Kuivaniemi $\mathrm{H}$ and Tromp G: Type III collagen (COL3A1): Gene and protein structure, tissue distribution, and associated diseases. Gene 707: 151-171, 2019. PMID: 31075413. DOI: 10.1016/j.gene.2019.05.003 
153 Yuan L, Shu B, Chen L, Qian K, Wang Y, Qian G, Zhu Y, Cao $\mathrm{X}$, Xie C, Xiao Y and Wang X: Overexpression of COL3A1 confers a poor prognosis in human bladder cancer identified by co-expression analysis. Oncotarget 8(41): 70508-70520, 2017. PMID: 29050298. DOI: 10.18632/oncotarget.19733

154 Santala M, Simojoki M, Risteli J, Risteli L and Kauppila A: Type I and III collagen metabolites as predictors of clinical outcome in epithelial ovarian cancer. Clin Cancer Res 5(12): 4091-4096, 1999. PMID: 10632345.

155 Liu Y, Cai Y, Liu L, Wu Y and Xiong X: Crucial biological functions of CCL7 in cancer. PeerJ 6: e4928, 2018. PMID: 29915688. DOI: 10.7717 peerj.4928

156 Ding M, Sun X, Zhong J, Zhang C, Tian Y, Ge J, Zhang CY, Zen K, Wang JJ, Zhang C and Wang C: Decreased miR-200a$3 p$ is a key regulator of renal carcinoma growth and migration by directly targeting CBL. J Cell Biochem 119(12): 9974-9985, 2018. PMID: 30171729. DOI: 10.1002/jcb.27326

157 Lyle CL, Belghasem M and Chitalia VC: c-Cbl: An important regulator and a target in angiogenesis and tumorigenesis. Cells 8(5): 2019. PMID: 31126146. DOI: 10.3390/cells 80 50498

158 Singh AJ, Meyer RD, Navruzbekov G, Shelke R, Duan L, Band $\mathrm{H}$, Leeman SE and Rahimi N: A critical role for the E3-ligase activity of c-Cbl in VEGFR-2-mediated PLCgamma1 activation and angiogenesis. Proc Natl Acad Sci USA 104(13): 5413-5418, 2007. PMID: 17372230. DOI: 10.1073/pnas.0700809104

159 Ding M, Lu X, Wang C, Zhao Q, Ge J, Xia Q, Wang J, Zen K, Zhang CY and Zhang C: The E2F1-miR-520/372/373-SPOP axis modulates progression of renal carcinoma. Cancer Res 78(24): 6771-6784, 2018. PMID: 30348808. DOI: 10.1158/00085472.CAN-18-1662

160 Choo KB, Chuang TJ, Lin WY, Chang CM, Tsai YH and Huang CJ: Evolutionary expansion of SPOP and associated TD/POZ gene family: Impact of evolutionary route on gene expression pattern. Gene 460(1-2): 39-47, 2010. PMID: 20399258. DOI: 10.1016/j.gene.2010.04.003

161 Guo ZQ, Zheng T, Chen B, Luo C, Ouyang S, Gong S, Li J, Mao LL, Lian F, Yang Y, Huang Y, Li L, Lu J, Zhang B, Zhou L, Ding H, Gao Z, Zhou L, Li G, Zhou R, Chen K, Liu J, Wen Y, Gong L, Ke Y, Yang SD, Qiu XB, Zhang N, Ren J, Zhong D, Yang CG, Liu J and Jiang H: Small-molecule targeting of e3 ligase adaptor SPOP in kidney cancer. Cancer Cell 30(3): 474 484, 2016. PMID: 27622336. DOI: 10.1016/j.ccell.2016.08.003

162 Patel HV, Doppalapudi SK and Singer EA: Taking a SPOP at renal cell carcinoma - unraveling a novel pathway for tumor progression in clear cell RCC. EBioMedicine 56: 102823, 2020. PMID: 32512506. DOI: 10.1016/j.ebiom.2020.102823

163 Harb OA, Elfeky MA, El Shafaay BS, Taha HF, Osman G, Harera IS, Gertallah LM, Abdelmonem DM and Embaby A: SPOP, ZEB-1 and E-cadherin expression in clear cell renal cell carcinoma (cc-RCC): Clinicopathological and prognostic significance. Pathophysiology 25(4): 335-345, 2018. PMID: 29801752. DOI: $10.1016 /$ j.pathophys.2018.05.004

164 Zheng T and Yang CG: Targeting SPOP with small molecules provides a novel strategy for kidney cancer therapy. Sci China Life Sci 60(1): 91-93, 2017. PMID: 27888385. DOI: 10.1007/s11427016-0297-2

165 Zhuang Q, Shen J, Chen Z, Zhang M, Fan M, Xue D, Lu H, Xu R, He X and Hou J: MiR-337-3p suppresses the proliferation and metastasis of clear cell renal cell carcinoma cells via modulating Capn4. Cancer Biomark 23(4): 515-525, 2018. PMID: 30452399. DOI: 10.3233/CBM-181645

166 Perrin BJ and Huttenlocher A: Calpain. Int J Biochem Cell Biol 34(7): 722-725, 2002. PMID: 11950589. DOI: 10.1016/s13572725(02)00009-2

167 Storr SJ, Carragher NO, Frame MC, Parr T and Martin SG: The calpain system and cancer. Nat Rev Cancer 11(5): 364-374, 2011. PMID: 21508973. DOI: $10.1038 / \mathrm{nrc} 3050$

168 Chen J, Wu Y, Zhang L, Fang X and Hu X: Evidence for calpains in cancer metastasis. J Cell Physiol 234(6): 8233-8240, 2019. PMID: 30370545. DOI: $10.1002 /$ jcp. 27649

169 Peng P, Min L, Song S, Zhao J, Li L, Yang C, Shao M, Zhang M, Wu H, Zhang J, Li C, Wang X, Wang H, Qin J, Ruan Y and $\mathrm{Gu} \mathrm{J}$ : Elevated expression of Calpain-4 predicts poor prognosis in patients with gastric cancer after gastrectomy. Int J Mol Sci 17(10): 2016. PMID: 27689993. DOI: 10.3390/ijms17101612

170 Kim EA, Kim SW, Nam J, Sung EG, Song IH, Kim JY, Kwon TK and Lee TJ: Inhibition of c-FLIPL expression by miRNA708 increases the sensitivity of renal cancer cells to anti-cancer drugs. Oncotarget 7(22): 31832-31846, 2016. PMID: 27092874. DOI: $10.18632 /$ oncotarget.7149

171 Safa AR:c-FLIP, a master anti-apoptotic regulator. Exp Oncol 34:176-184, 2012. PMID: 23070002.

172 Shirley S and Micheau O: Targeting c-FLIP in cancer. Cancer Lett 332(2): 141-150, 2013. PMID: 21071136. DOI: 10.1016/ j.canlet.2010.10.009

173 Humphreys L, Espona-Fiedler M and Longley DB: FLIP as a therapeutic target in cancer. FEBS J 285(22): 4104-4123, 2018. PMID: 29806737. DOI: 10.1111/febs.14523

174 Saini S, Yamamura S, Majid S, Shahryari V, Hirata H, Tanaka $\mathrm{Y}$ and Dahiya R: MicroRNA-708 induces apoptosis and suppresses tumorigenicity in renal cancer cells. Cancer Res 71(19): 6208-6219, 2011. PMID: 21852381. DOI: 10.1158/0008-5472.CAN-11-0073

175 Parker AS, Kosari F, Lohse CM, Houston Thompson R, Kwon ED, Murphy L, Riehle DL, Blute ML, Leibovich BC, Vasmatzis $\mathrm{G}$ and Cheville JC: High expression levels of survivin protein independently predict a poor outcome for patients who undergo surgery for clear cell renal cell carcinoma. Cancer 107(1): 3745, 2006. PMID: 16736510 . DOI: $10.1002 / \mathrm{cncr} .21952$

176 Altieri DC: Survivin, cancer networks and pathway-directed drug discovery. Nat Rev Cancer 8(1): 61-70, 2008. PMID: 18075512. DOI: $10.1038 / \mathrm{nrc} 2293$

177 Martínez-García D, Manero-Rupérez N, Quesada R, KorrodiGregório L and Soto-Cerrato V: Therapeutic strategies involving survivin inhibition in cancer. Med Res Rev 39(3): 887-909, 2019. PMID: 30421440. DOI: 10.1002/med.21547

$178 \mathrm{Li} \mathrm{F}$, Aljahdali I and Ling X: Cancer therapeutics using survivin BIRC5 as a target: What can we do after over two decades of study?. J Exp Clin Cancer Res 38(1): 368, 2019. PMID: 31439015. DOI: 10.1186/s13046-019-1362-1

179 Fang JH, Zhou HC, Zeng C, Yang J, Liu Y, Huang X, Zhang JP, Guan XY and Zhuang SM: MicroRNA-29b suppresses tumor angiogenesis, invasion, and metastasis by regulating matrix metalloproteinase 2 expression. Hepatology 54(5): 17291740, 2011. PMID: 21793034. DOI: 10.1002/hep.24577

180 Chung AS, Lee J and Ferrara N: Targeting the tumour vasculature: Insights from physiological angiogenesis. Nat Rev Cancer 10(7): 505-514, 2010. PMID: 20574450. DOI: 10.1038/ $\operatorname{nrc} 2868$ 
181 Winer A, Adams S and Mignatti P: Matrix metalloproteinase inhibitors in cancer therapy: Turning past failures into future successes. Mol Cancer Ther 17(6): 1147-1155, 2018. PMID: 29735645. DOI: 10.1158/1535-7163.MCT-17-0646

182 Mikhaylova O, Stratton Y, Hall D, Kellner E, Ehmer B, Drew AF, Gallo CA, Plas DR, Biesiada J, Meller J and CzyzykKrzeska MF: VHL-regulated MiR-204 suppresses tumor growth through inhibition of LC3B-mediated autophagy in renal clear cell carcinoma. Cancer Cell 21(4): 532-546, 2012. PMID: 22516261. DOI: 10.1016/j.ccr.2012.02.019

183 Cao Q and Bai P: Role of autophagy in renal cancer. J Cancer 10(11): 2501-2509, 2019. PMID: 31258756. DOI: 10.7150/ jca. 29285

184 Onorati AV, Dyczynski M, Ojha R and Amaravadi RK: Targeting autophagy in cancer. Cancer 124(16): 3307-3318, 2018. PMID: 29671878. DOI: 10.1002/cncr.31335

185 Levy JMM, Towers CG and Thorburn A: Targeting autophagy in cancer. Nat Rev Cancer 17(9): 528-542, 2017. PMID: 28751651. DOI: $10.1038 /$ nrc.2017.53

186 Huang Y, Wu Y, Zeng L, Shan W and Huang L: The tumor suppressor role of microRNA-338-3p in renal cell carcinoma. Oncol Lett 16(2): 2195-2200, 2018. PMID: 30008918. DOI: 10.3892/ol.2018.8914

187 Walczak CE, Vernos I, Mitchison TJ, Karsenti E and Heald R: A model for the proposed roles of different microtubule-based motor proteins in establishing spindle bipolarity. Curr Biol 8(16): 903-913, 1998. PMID: 9707401. DOI: 10.1016/s0960-9822(07)00370-3

188 Xiao YX and Yang WX: KIFC1: a promising chemotherapy target for cancer treatment? Oncotarget 7(30): 48656-48670, 2016. PMID: 27102297. DOI: 10.18632/oncotarget.8799

189 Rath O and Kozielski F: Kinesins and cancer. Nat Rev Cancer 12(8): 527-539, 2012. PMID: 22825217. DOI: 10.1038/nrc3310

190 Myers SM and Collins I: Recent findings and future directions for interpolar mitotic kinesin inhibitors in cancer therapy. Future Med Chem 8(4): 463-489, 2016. PMID: 26976726. DOI: 10.4155/fmc. 16.5

191 Lin SJ, Yang DR, Yang G, Lin CY, Chang HC, Li G and Chang C: TR2 and TR4 orphan nuclear receptors: An overview. Curr Top Dev Biol 125: 357-373, 2017. PMID: 28527578. DOI: 10.1016/bs.ctdb.2017.02.002

192 Bai J, Yeh S, Qiu X, Hu L, Zeng J, Cai Y, Zuo L, Li G, Yang $\mathrm{G}$ and Chang C: TR4 nuclear receptor promotes clear cell renal cell carcinoma (ccRCC) vasculogenic mimicry (VM) formation and metastasis via altering the miR490-3p/vimentin signals. Oncogene 37(44): 5901-5912, 2018. PMID: 29973687. DOI: 10.1038/s41388-018-0269-1

193 Satelli A and Li S: Vimentin in cancer and its potential as a molecular target for cancer therapy. Cell Mol Life Sci 68(18): 3033-3046, 2011. PMID: 21637948. DOI: 10.1007/s00018-0110735-1

194 Saitoh M: Involvement of partial EMT in cancer progression. J Biochem 164(4): 257-264, 2018. PMID: 29726955. DOI: 10.1093/jb/mvy047

195 Li W, Liu M, Feng Y, Xu YF, Huang YF, Che JP, Wang GC, Yao XD and Zheng JH: Downregulated miR-646 in clear cell renal carcinoma correlated with tumour metastasis by targeting the nin one binding protein (NOB1). Br J Cancer 111(6): 11881200, 2014. PMID: 25010867. DOI: 10.1038/bjc.2014.382

196 Fasanaro P, Capogrossi MC and Martelli F: Regulation of the endothelial cell cycle by the ubiquitin-proteasome system.
Cardiovasc Res 85(2): 272-280, 2010. PMID: 19617222. DOI: $10.1093 / \mathrm{cvr} / \mathrm{cvp} 244$

$197 \mathrm{Ke} \mathrm{W,} \mathrm{Lu} \mathrm{Z} \mathrm{and} \mathrm{Zhao} \mathrm{X:} \mathrm{NOB1:} \mathrm{A} \mathrm{potential} \mathrm{biomarker} \mathrm{or} \mathrm{target}$ in cancer. Curr Drug Targets 20(10): 1081-1089, 2019. PMID: 30854959. DOI: $10.2174 / 1389450120666190308145346$

198 Fatica A, Oeffinger M, Dlakić M and Tollervey D: Nob1p is required for cleavage of the 3' end of $18 \mathrm{~S}$ rRNA. Mol Cell Biol 23(5): 1798-1807, 2003. PMID: 12588997. DOI: 10.1128/mcb. 23.5.1798-1807.2003

199 Lamanna AC and Karbstein K: Nob1 binds the single-stranded cleavage site D at the 3'-end of 18S rRNA with its PIN domain. Proc Natl Acad Sci USA 106(34): 14259-14264, 2009. PMID: 19706509. DOI: $10.1073 /$ pnas.0905403106

200 Ling H, Fabbri M and Calin GA: MicroRNAs and other noncoding RNAs as targets for anticancer drug development. Nat Rev Drug Discov 12(11): 847-865, 2013. PMID: 24172333. DOI: $10.1038 / \mathrm{nrd} 4140$

201 Broderick JA and Zamore PD: MicroRNA therapeutics. Gene Ther 18(12): 1104-1110, 2011. PMID: 21525952. DOI: $10.1038 /$ gt.2011.50

202 Gambari R, Brognara E, Spandidos DA and Fabbri E: Targeting oncomiRNAs and mimicking tumor suppressor miRNAs: New trends in the development of miRNA therapeutic strategies in oncology (Review). Int J Oncol 49(1): 5-32, 2016. PMID: 27175518. DOI: $10.3892 /$ ijo.2016.3503

203 Nickerson ML, Jaeger E, Shi Y, Durocher JA, Mahurkar S, Zaridze D, Matveev V, Janout V, Kollarova H, Bencko V, Navratilova M, Szeszenia-Dabrowska N, Mates D, Mukeria A, Holcatova I, Schmidt LS, Toro JR, Karami S, Hung R, Gerard GF, Linehan WM, Merino M, Zbar B, Boffetta P, Brennan P, Rothman N, Chow WH, Waldman FM and Moore LE: Improved identification of von Hippel-Lindau gene alterations in clear cell renal tumors. Clin Cancer Res 14(15): 4726-4734, 2008. PMID: 18676741. DOI: 10.1158/1078-0432.CCR-07-4921

204 Jonasch E, Donskov F, Iliopoulos O, Rathmell W, Narayan V, Maughan B, Oudard S, Else T, Maranchie J, Welsh S, Thamake S, Park E, Zojwalla N, Perini R, Linehan W and Srinivasan R: Phase II study of the oral HIF-2 $\alpha$ inhibitor MK-6482 for Von Hippel-Lindau disease-associated renal cell carcinoma. Journal of Clinical Oncology 38(15_suppl): 5003-5003, 2020. DOI: 10.1200/JCO.2020.38.15_suppl.5003

205 Fallah J and Rini BI: HIF inhibitors: Status of current clinical development. Curr Oncol Rep 21(1): 6, 2019. PMID: 30671662. DOI: 10.1007/s11912-019-0752-z

206 Logan JE, Mostofizadeh N, Desai AJ, VON Euw E, Conklin D, Konkankit V, Hamidi H, Eckardt M, Anderson L, Chen HW, Ginther C, Taschereau E, Bui PH, Christensen JG, Belldegrun AS, Slamon DJ and Kabbinavar FF: PD-0332991, a potent and selective inhibitor of cyclin-dependent kinase 4/6, demonstrates inhibition of proliferation in renal cell carcinoma at nanomolar concentrations and molecular markers predict for sensitivity. Anticancer Res 33(8): 2997-3004, 2013. PMID: 23898052.

207 Jones D: Setbacks shadow microRNA therapies in the clinic. Nat Biotechnol 36(10): 909-910, 2018. PMID: 30307922. DOI: $10.1038 /$ nbt 1018-909 